\title{
QUANTIFYING THE RURAL-URBAN GRADIENT IN LATIN AMERICA AND THE CARIBBEAN
}

\author{
Kenneth M. Chomitz, Piet Buys, and Timothy S. Thomas
}

\begin{abstract}
This paper addresses the deceptively simple question: what is the rural population of Latin America and the Caribbean? It argues that rurality is a gradient, not a dichotomy, and nominates two dimensions to that gradient: population density, and remoteness from large metropolitan areas. It uses geographically referenced population data (from the Gridded Population of the World, version 3) to tabulate the distribution of populations in Latin America, and in individual countries, by population density and by remoteness. It finds that the popular perception of Latin America as a 75\% urban continent is misleading. Official census criteria, though inconsistent between countries, tend to classify as 'urban' small settlements of less than 2000 people. Many of these settlements are however embedded in an agriculturally based countryside. The paper finds that about $13 \%$ of LAC populations live at ultra-low densities, of less than 20 per square kilometer. Essentially all these people are more than an hour distant from a large city, and more than half live more than four hours distant. A quarter of LAC population is estimated to live at densities below 50, again essentially all of them more than an hour distant from a large city. Almost half $(46 \%)$ of LAC lives at population densities below 150 (a conventional threshold for urban areas), and more than $90 \%$ of this group is at least an hour distant from a city; about a third of them $(18 \%$ of LAC total) are more than four hours' distant from a large city.
\end{abstract}

World Bank Policy Research Working Paper 3634, June 2005

The Policy Research Working Paper Series disseminates the findings of work in progress to encourage the exchange of ideas about development issues. An objective of the series is to get the findings out quickly, even if the presentations are less than fully polished. The papers carry the names of the authors and should be cited accordingly. The findings, interpretations, and conclusions expressed in this paper are entirely those of the authors. They do not necessarily represent the view of the World Bank, its Executive Directors, or the countries they represent. Policy Research Working Papers are available online at http:/ / econ.worldbank.org.

Acknowledgments: This paper was prepared as a background paper to Beyond the City: The rural contribution to development. We are grateful to Andrew Nelson and Juan Robalino (who contributed to a precursor versions of this work), and thank Uwe Deichmann and Deborah Balk for helpful comments. We are very grateful to CIESIN for sharing the GPW3 data. The denominations used and the boundaries shown on maps herein do not imply, on the part of the World Bank, any judgment on the legal basis of any territory or any endorsement or acceptance of such boundaries. 


\section{Motivation and overview}

How many rural people live in Latin American and the Caribbean (LAC)? The question is simple to pose but not well-defined. "Rurality" has many aspects and connotations. For policy purposes we need to specify precisely which aspects of rurality interest us, and define criteria for identifying these aspects. Moreover, we should not expect that any of this criteria exhibit marked break points between rural and urban areas or people. However defined, rurality is a gradient, not a discrete condition.

Here we apply two criteria for defining the rurality: population density, and remoteness from large cities. We argue that these criteria constitute important gradients along which economic behavior and appropriate development interventions might vary substantially. Where population densities are low, markets of all kinds are thin, and unit costs of delivering most social services and many types of infrastructure are high. Where large urban areas are distant, farmgate (or factory-gate) prices of outputs will be low and prices of inputs will be high, and it will be difficult to recruit skilled personnel to public service or private enterprises. Thus remoteness and low population density together define a set of rural areas that face special challenges in development.

Remoteness and population density alone, however, cannot begin to capture the heterogeneity that exists within rural areas. Many aspects of physical geography shape opportunities and constraints for rural development, and environment-development linkages. Here we focus on two summary measures of physical geography: agroclimatic suitability for cropping, and forest cover.

With rurality criteria and descriptors defined, it is possible to tabulate rural populations using one of the existing global gridded population coverages. The two main candidate datasets Landscan, and the GPW - each have advantages and disadvantages. We chose to use the GPW 3, in part out of anticipation of a forthcoming GPW refinement which should give an improved measure of population distributions.

Using GPW 3, we tabulate the cumulative distribution of population and land area by population density. We perform these tabulations for LAC as a whole and for the larger individual countries. We partition the population distributions by remoteness, cropping suitability, forest cover, and biome. We do not nominate a threshold population density cutoff for determining rurality, leaving that to the user of this information.

\section{Criteria for rurality}

'Rurality' and 'urbanity' are comfortable but imprecise terms. On the surface, they seem to express a clear and meaningful dichotomy. We anchor the concepts with contrasting images of an isolated, bucolic farm on the one hand, a conglomeration of skyscrapers and slums on the other. The opportunities, constraints, and living conditions in these two locales are 
obviously different. So it is natural to seek a binary indicator of rural vs. urban location and to use it for analytic and policy purposes.

There is no international standard for making this dichotomy, and indeed the United Nations argues that "given the variety of situations in the countries of the world, it is not possible or desirable to adopt uniform criteria to distinguish urban areas from rural areas" (United Nations 2002, p. 106). Accordingly, the official United Nations statistics on urban and rural populations are based on the inconsistent national standards.

Table 1 reproduces the United Nations' compilation of rurality estimates for most LAC countries, together with the national criteria for urban areas. Almost all countries have adopted an urban classification related to the size or characteristics of settlements. Some use a minimum population, typically 1500 to 2500 people; others designate as urban the administrative seat of a municipio or equivalent; others use as criteria the presence of infrastructure such as paved roads, street lights, schools and medical facilities.

On reflection, however, it is clear that an urban/rural dichotomy is an oversimplification. The two emblematic images - isolated farm, thriving metropolis -- represent poles on a continuum. Life changes along a variety of dimensions, as one journeys from the most remote forest outpost through fields and pastures, past tiny hamlets, through small towns with weekly farm markets, into intensively cultivated areas near larger towns and small cities, eventually reaching the center of a cosmopolitan megacity. The changes may sometimes be abrupt, more often gradual. Agriculture declines as a source of income and employment. Land uses tend to shift, as von Thünen described, from forestry to pasture to crops to vegetables, becoming more intensive as larger cities are approached. The proportion of indigenous people may decrease, reflecting historical patterns of settlement or exclusion. Access to infrastructure, to social services and to nonfarm employment all increase, and with them population density and incomes. Along this continuum from urban to rural, the village of 1500 people - the typical statistical office's threshold of urbanity - is arguably closer to the rural pole than the urban, and probably embraces many settlements that are physically and economically embedded in agricultural landscapes.

Here we propose that operational definitions of rurality can be based on two main criteria or dimensions: population density, and distance to large cities (those with populations greater than 100,000). Population density is an important criterion both for economic behavior and for development policy. Population density drives the agglomeration economies that are defining feature of cities (though urban transport, infrastructure, and amenities also bear on those economies). Population density also strongly affects the unit costs of a variety of public and private investments related to development. Economies of density arise either because of fixed facility costs, or as a result of higher mean travel costs to reach households. There are for instance economies of density in the provision of elementary education, public health, agricultural extension, grid linked electricity, and feeder roads. Low population density areas may be too small to support competition in some product and service markets (especially transportation), leading to capture by local monopolies. Each of these consideration may have a different relationship with density, and with other factors, making it difficult to designate a unique urban-rural cutoff density. As a reference, however, Bollman and Bryden (1997, p.9), cite OECD adoption of 150 people $/ \mathrm{km}^{2}$ as the urban threshold. 
Access to major urban centers is another aspect of the urban-rural gradient that captures important determinants of economic opportunities and constraints. Areas within easy commuting radius of a major urban center can for many purposes be considered urban, even if occupied by farmsteads. The edge of this commuting radius may constitute a meaningful break-point or discontinuity on the urban-rural divide, though it is not sharply delineated. At slightly larger radii, farm and nonfarm households may still enjoy some urban employment opportunities, and can profitably grow fruits and vegetables for urban markets. Perhaps there is another meaningful breakpoint, though even less sharply defined, at the von Thünen distance associated with truck farming for urban consumption. As remoteness increases to market increases still further, von Thünen teaches us that activities will systematically change ${ }^{1}$. Households will either move to production of goods with low relative transport costs, or shift towards subsistence production. There will also be a strong though not universal tendency for population density to decline as remoteness increases.

Figure 1, taken from Chomitz and Nelson (2003), illustrates the rural urban gradient in the context of Nicaragua. Based on municipio-level data it shows the strong correlation between travel time to Managua, incidence of severe rural poverty, and low population density (all measured in logs). The tightness and smoothness of the relation is remarkable. However, the graphs exclude the six municipios of Managua Department, which show a sharply lower poverty rate than would be predicted by travel time alone.

Areas towards the rural end of the density and remoteness gradient are by no means homogeneous. Rural development policies may be profoundly influenced by two important environmental factors: agroclimatic suitability for cropping, and current forest cover. These factors are important determinants of the prospects for agriculturally-led rural development, and of the potential effect of development on environmental externalities. Both factors are best viewed as continuous variables.

In summary, we propose to define urban-rural gradients along two dimensions: population density, and remoteness from large cities. Two subsidiary additional dimensions will be used to characterize populations and land areas: agricultural suitability and forest cover.

\section{Data for construction of rurality gradients}

\section{Population density}

Population density is a scale-dependent concept. The population density at a point is, in principle, the mean number of persons per square kilometer evaluated within a radius $r$ of the point and thus should vary continuously over the landscape. The choice of $\mathrm{r}$ depends, ideally, on the application for which density is needed. For many of the infrastructure and service delivery issues mentioned above, $\mathrm{r}$ might be on the order of a few to several kilometers.

\footnotetext{
${ }^{1}$ In reality, land use is affected not just by market distance, but by soil and climate conditions. For this reason, clearly-delimited von Thünen rings are not always observed. See Chomitz and Gray (1996) for an empirical land use model of Belize that incorporates both market access and agroclimate in explaining the allocation of land between commercial farming, subsistence farming, and forest.
} 
In practice we are constrained by the spatial resolution of available data. Census bureaus typically report this data for second-level administrative districts (e.g., municipios), although in some cases (such as Brazil) census tract level data is published. The reporting units differ widely in size.

Two consortia have independently tackled the task of assembling global population census data and using it to assign densities to finely-gridded geographic cells, so as to permit geographic analysis of the correlates of population. They have adopted complementary approaches, each with advantages and disadvantages.

Landscan, developed by the Oak Ridge National Laboratory (http://www.ornl.gov/sci/gist/landscan/) uses census source data typically at the province level. They then use an unpublished model to allocate population within the province level, based on road proximity, slope, landcover, and 'nighttime lights'. The latter is a map derived from satellite images of artificial illumination, and is a useful proxy for the location of cities, towns, and major roads. (though the relation between population and illumination is of course modulated by income). Landscan's goal is to represent population density averaged over a 24 hour day, thus blending both occupational and residential locations. The results are gridded to $0.5^{\prime}$ by $0.5^{\prime}$ grid cells ${ }^{2}$.

GPW3 (the Gridded Population of the World) is produced by CIESIN, Columbia University, and CIAT ${ }^{3}$. It employs $2.5^{\prime}$ x 2.5 ' grid cells. It uses mostly lower-administrativelevel (higher resolution) census source data, typically at the level of the municipio or equivalent. The current version, GPW3, then assumes homogeneous distribution of population within the administrative unit. Table 6 reports, by country, the administrative level and the total number of units used. A forthcoming version, GRUMP v1 ${ }^{4}$, documented in Balk et al. (2004) allocates reported within-unit urban population to grid cells with known light areas (to proxy for built up areas), based night-time illumination spots, coordinates of cities, and satellite imagery. It assumes homogeneous distribution of the remaining population to non-illuminated grid cells, within administrative areas.

A summary table comparing the data sources is displayed below. This draft is based on GPW3. GRUMP v1 is expected to be released shortly, and we intend to use it to reevaluate the results when it becomes available. The reader should keep in mind that inter-country

20.5 arc-minutes; there are 60 arc-minutes in a degree of latitude or longitude. At the equator, a one-degree grid cell is about $111 \mathrm{~km}$ on a side, so $0.5^{\prime}$ is approximately a kilometer at the equator. The length of a degree of longitude shrinks towards 0 at the poles, so grid cells vary in size.

${ }^{3}$ Center for International Earth Science Information Network (CIESIN), Columbia University; and Centro Internacional de Agricultura Tropical

(CIAT), 2004. Gridded Population of the World, version 3, Palisades, NY:

CIESIN, Columbia University. available from

http://beta.sedac.ciesin.columbia.edu/gpw

${ }^{4}$ Center for International Earth Science Information Network (CIESIN),

Columbia University; International Food Policy Research Institute (IPFRI), the World Bank; and Centro

Internacional de Agricultura Tropical (CIAT),2004. Global Rural-Urban Mapping Project (GRUMP): Gridded Population of theWorld, version 3, with Urban Reallocation (GPW-UR). Palisades, NY: CIESIN,Columbia University 
comparability is hampered by inter-country differences in defining muncipios or equivalent lower-level administrative districts. For instance, the GPW3 data for Peru is based on 1895 third-level units, Bolivia on just 100 second-level. All intercountry comparisons should be approached with caution.

\begin{tabular}{|c|c|c|c|}
\hline & Landscan & GPW 3 & GRUMP v1 \\
\hline Produced by & $\begin{array}{ll}\text { Oak Ridge } & \text { National } \\
\text { Laboratory } & \end{array}$ & CIESIN and CIAT & $\begin{array}{l}\text { CIESIN, IFPRI, } \\
\text { World Bank, and } \\
\text { CIAT }\end{array}$ \\
\hline $\begin{array}{l}\text { Nominal year of } \\
\text { data }\end{array}$ & 2002 & 2000 & 2000 \\
\hline Grid cell size & $0.5^{\prime}$ & $2.5^{\prime}$ & $1 \mathrm{~km}$ \\
\hline \begin{tabular}{lr}
\multicolumn{2}{c}{ Typical level of } \\
unit for which \\
input & census \\
data & was \\
obtained &
\end{tabular} & province/state & $\begin{array}{l}\text { municipio/county, } \\
\text { varies by country }\end{array}$ & municipio/county \\
\hline $\begin{array}{l}\text { Within-unit } \\
\text { allocation of } \\
\text { population }\end{array}$ & $\begin{array}{l}\text { model based on road } \\
\text { proximity, slope, land } \\
\text { cover, urban lights }\end{array}$ & homogeneous & $\begin{array}{l}\text { reported urban } \\
\text { population allocated } \\
\text { to cells of known } \\
\text { light areas and used } \\
\text { as a means for } \\
\text { reallocating } \\
\text { population estimates } \\
\text { of administrative } \\
\text { areas }\end{array}$ \\
\hline
\end{tabular}

\section{Accessibility}

We used an accessibility map constructed by Andrew Nelson, based on the DCW (Digital Chart of the World). This was the only available source of pan-continental road data, and is based on old and possibly inconsistent data. We arbitrarily assigned travel speeds of $10 \mathrm{~km} / \mathrm{hr}$ to $60 \mathrm{~km} / \mathrm{hr}$ to roads of increasing quality, and $4 \mathrm{~km} / \mathrm{hr}$ to off-road travel. These speed estimates were used to compute an accessibility map depicting the minimum travel time in hours, and distance in kilometers, along the fastest path, from each point to the nearest city of 100,000 or more (according to the DCW). Although our travel speed estimates are arbitrary, they are arguably better than an assumption of constant travel speed regardless of terrain. The resultant map (figure 2) appears to underestimate current accessibility in parts of the Brazilian Amazon. We emphasize that this map should be viewed only as a crude index rather than a literal measure of travel time, and stress the need for accurate, consistent national and continental maps of transportation networks. 


\section{Agricultural suitability and forest cover}

These data (see figure 4) were taken from the global agroecological zoning (GAEZ) data assembled by IIASA and FAO, (http://www.iiasa.ac.at/Research/LUC/GAEZ/index.htm, version 1.0). That exercise used agroclimatic data to create a suitability index (SI) for rainfed cropping under mixed input levels. Here we use categories from Plate 56, distinguishing marginal and unsuitable lands (SI <25) from more favorable lands, and distinguishing forested and nonforested areas.

\section{Data assembly}

We used the GPW grid cells as our reference. We defined population density as GPWreported population (UN adjusted) divided by reported non-water, non-ice area of the cell. Centroids of the GPW grid cells were used to extract data from the accessibility maps, the GAEZ data, and a dataset of country boundaries.

\section{Results}

Figure 4 maps the population density data from GPW 3. Keep in mind that these represent, for the most part, municipio level averages. Table 2 tabulates population proportions ${ }^{5}$, for LAC as a whole and for selected countries, by population density threshold, breaking out those areas more than one hour travel time from cities with more than 100,000 people (here designated as 'remote'). The proportions in all cases refer to the total national population, so for instance, we read that $46 \%$ of all Argentinians live at population densities below 150, and $44 \%$ of all Argentinians live in cells that both have densities below 150 and are more than one hour travel time from a city of 100,000. The appendix graphs this data in the the form of cumulative densities, showing for each density $d$, the proportion of national population (or area) with density less than or equal to d. Because we are agnostic about density thresholds, each graph is presented both on a density scale of 0 to 50 people $/ \mathrm{km} 2$, and on one of 0 to 500 people $/ \mathrm{km} 2$

According to the tabulations, about $13 \%$ of LAC populations live at ultra-low densities, of less than 20 per square kilometer. Essentially all these people are more than an hour distant from a large city, and more than half live more than four hours distant. This group plays a key role in environmental management, because they occupy the great bulk of the continent's territory and forests.

About a quarter of LAC population is estimated to live at densities below 50, again essentially all of them more than an hour distant from a large city, and nearly half in very remote ( $>4$ hours travel to a city) conditions. While this group may include some prosperous ranchers, it certainly contains a large number of very poor people. Almost half $(46 \%)$ of LAC lives at population densities below 150, and more than $90 \%$ of this group is at least an hour distant from a city, and about a third of them (18\% of LAC total) are more than four hours' distant (see table 3). Even at densities of up to 500, the great majority of

\footnotetext{
${ }^{5}$ Population totals are reported in table 6.
} 
people are more than an hour distant from cities. These estimates contrast sharply with the official estimate of an urban proportion of $75.8 \%$ for Latin America and the Caribbean ${ }^{6}$.

It is interesting to compare these results with early tabulations of GRUMP v1 (Balk, pers. comm.; see also Balk et al 2004). Those tabulations find about 36\% of LAC population living in settlements of less than 5000 people (including rural areas). Another $6 \%$ live in settlements of 5000-20000 population (with a mean population density of 332 - below some thresholds for urbanness). About 48\% live in settlements of greater than 100,000 population.

Figure 5 graphs the 'remote' ( $>1$ hour) columns of table 2, with countries arranged in ascending order according to the density-150 threshold. It shows that density-100, density150, and density-200 thresholds yield roughly the same ranking of countries, and roughly similar estimates of rurality. However, the density-20 threshold is very poorly correlated with the others. For instance, Costa Rica, Cuba, and Peru have roughly similar rural proportions according to the density- 150 threshold but Peru has proportionately far more people living at densities below 20 .

Figure 6 compares the density-150/>1 hour rurality criterion to census measures of rurality. There are some striking disparities. Census measures ascribe much lower rural populations to Argentina, Brazil, and Uruguay, and much lower populations to El Salvador and Guatemala, compared to the density/distance based measure.

Finally, tables 7 and 8 cross tabulate population and land area by population density, suitability for rainfed crops, and forest cover. About one fifth of LAC population lives at densities below 150 on non-forested areas, suitable for rainfed crops. They occupy 29\% of LAC's land area. Almost the same number of people live at densities under 150 and occupy land that is rated marginal or unsuitable for rainfed crops; these lands constitute $45 \%$ of LAC, including 16\% that is both poor for crops and under forest cover. And about $6 \%$ of the total population lives at densities $<150$, occupying land that is suitable for crops but currently largely forested. These lands, constituting about $25 \%$ of LAC, may present development-environment trade-offs.

\section{Conclusions}

The quantitative results presented here must be taken cautiously. They are very much affected by the size and heterogeneity of the reporting unit. They are not necessarily comparable between countries (though they may be more consistent than existing estimates). Because these population densities are computed, for the most part, over municipios, lowdensity areas are likely to contain market towns or even small cities. Thus the mean population densities tallied here do not closely correspond to the 'small-radius' ideal discussed above. The GRUMP v 1, when available, should provide an improved estimate of density distributions.

Our intention was to illustrate some general propositions:

\footnotetext{
${ }^{6}$ World Bank, The Little Green Data Book 2003.
} 
"Rurality" is a multidimensional concept. There are many aspects or characteristics associated with the vague concept of rurality, including access to social and infrastructure services, linkages to employment and commodity markets, involvement with agriculture and natural resources. These characteristics are correlated, but not perfectly so. Rural policy analysis should seek to precisely specify and measure the characteristics of interest.

Think of rural vs. urban as a gradient rather than a dichotomy. For many of the rural characteristics of interest, there does not appear to be a natural dividing line or break point between rural areas and urban areas. Behavior and conditions change drastically along the gradient, but there is no compelling reasons to segment it into just two categories.

Population density and remoteness from large cities constitute two useful 'general purpose' indicators of rurality. The use of population density emphasizes the continuous nature of the rural-urban gradient. Arguably, the development challenges at 2, 20, 200, and 2000 people per square kilometer are qualitatively quite distinct, even though the former three categories are traditionally lumped together as 'rural'.

Traditional census-measures of rurality in LAC exclude villages embedded in agricultural areas. Censuses tend to designate very small settlements as urban, implicitly using access to basic services (health clinic, school, paved road) as the criterion for urbanity. It is on this basis that LAC is designated as a mostly-urbanized continent. In fact, a large proportion of the population lives in areas of ambiguous urbanity: small, farm-oriented villages (population $<5000$ ) embedded in an agricultural countryside. And there are probably about as many people living in small towns $(5000-50,000)$ outside metropolitan areas, as in megacities.

Ultimately this re-examination of measures of rurality leads us to question the utility of the concept of 'rurality' or 'rural policy'. The simplistic notion of a rural-urban dichotomy, combined with implicit and inconsistent notions of what constitutes a dividing line between the two, may be a hindrance rather than an aid to formulating regionally-articulated development policies. 


\section{References}

Balk, Deborah, F. Pozzi, U. Deichmann, G. Yetman, A. Nelson. 2004. The Distribution of People and the Dimension of Place: Methodologies to Improve the Global Estimation of Urban Extents. CIESIN. processed.

R.D. Bollman and J.D. Bryden, eds. (1997). Rural Employment: An International Perspective. New York: CAB International.

Chomitz, K.M. and D. Gray (1996) "Roads, land use, and deforestation: a spatial model applied to Belize". World Bank Economic Review 10(3), September 1996, 487-512.

Chomitz, K.M. and Andrew Nelson. (2003) "The Geographical Poverty Gradient in Nicaragua and its Implications for Rural Development Strategy." World Bank, processed.

United Nations (2002). World Urbanization Prospects: The 2001 Revision. Publication ST/ESA/SER.A/216. New York, United Nations. 


\section{Table 1 Urban definitions and rural proportions according to national statistical offices}

Sources: Rural population from World Development Indicators, based on United Nations (2002); Urban definitions from United Nations (2002)

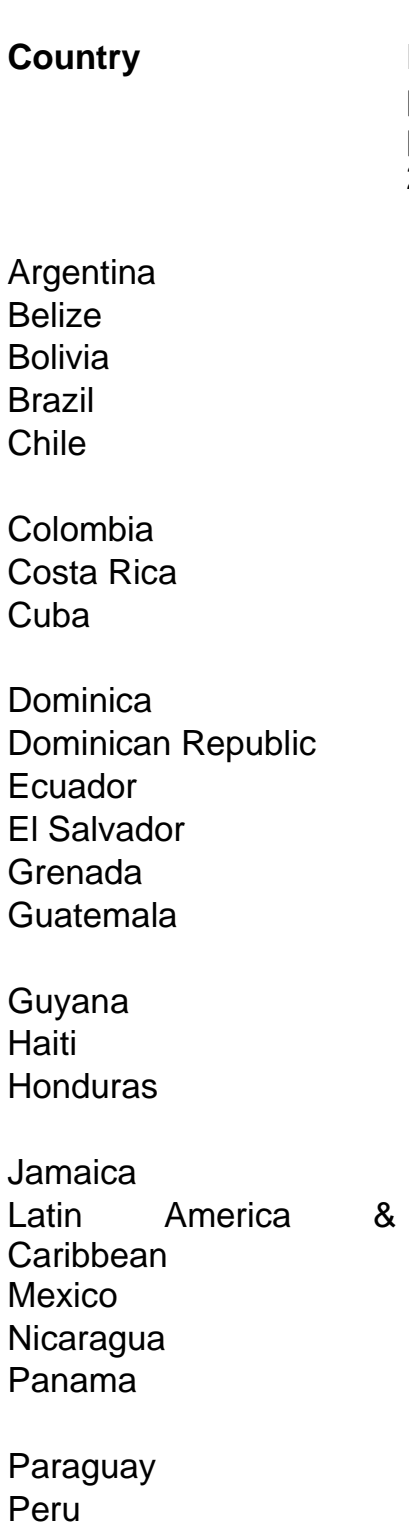

St. Kitts and Nevis

St. Lucia

St. Vincent and the Grenadines

Suriname

Trinidad and Tobago

Uruguay

Venezuela, RB

Urban definition based on:

\begin{tabular}{|c|c|c|}
\hline $\begin{array}{l}\text { Rural } \\
\text { population } \\
\text { percentage, } \\
2002\end{array}$ & $\begin{array}{l}\text { Size threshold } \\
\text { for localities }\end{array}$ & $\begin{array}{l}\text { Administrative Other } \\
\text { centers of } \\
\text { municipios, } \\
\text { cantons, } \\
\text { provinces }\end{array}$ \\
\hline
\end{tabular}

8.0

51.8

36.6

17.8

13.7

24.0

40.0

24.3

28.3

33.5

36.1

37.6

61.0

59.7

62.9

63.0

45.5

42.9

23.8

25.2

43.1

43.1

42.7

$26.5>100$ dwellings

65.5

61.7

43.0

24.7

25.1

7.7

12.6
2000

2000

$\mathrm{X}$

Populated centers with urban characteristics

1500

2000

X or with specified infrastructure services.

500

$X$
$X$
$X$

$X$ (communes) 2000

$x$
$x$
$x$

two urban parishes

plus entire municipio of Guatemala

three cities

and with a set of specified infrastructure services selected towns not applicable

2500

1500

$x$

and with a set of specified infrastructure services

(satisfies dwelling or administrative criteria)

Basseterre and Charlestown

Castries

Not available

Greater Paramaribo

selected towns

officially defined cities 
Table 2. Proportion of total population, by population density and remoteness

\begin{tabular}{|c|c|c|c|c|c|c|c|c|c|c|}
\hline \multicolumn{11}{|c|}{$\begin{array}{l}\text { Population density per square } \\
\text { kilometer }\end{array}$} \\
\hline$<20$ & $<$ & & $<1$ & & $<1$ & & $<2$ & & $<5$ & \\
\hline 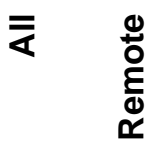 & $\overline{\bar{\alpha}}$ & 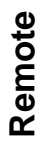 & $\overline{\bar{\alpha}}$ & 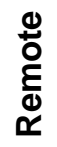 & $\bar{\varepsilon}$ & 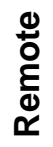 & $\overline{\bar{\alpha}}$ & 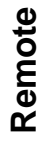 & $\overline{\bar{\alpha}}$ & \\
\hline
\end{tabular}

$\begin{array}{lrrrrrrrrrrrr}\text { Argentina } & 26 \% & 25 \% & 37 \% & 36 \% & 42 \% & 41 \% & 46 \% & 44 \% & 48 \% & 45 \% & 54 \% & 48 \% \\ \text { Bolivia } & 33 \% & 33 \% & 43 \% & 42 \% & 54 \% & 51 \% & 56 \% & 53 \% & 58 \% & 55 \% & 93 \% & 80 \% \\ \text { Brazil } & 18 \% & 17 \% & 34 \% & 33 \% & 47 \% & 44 \% & 54 \% & 49 \% & 57 \% & 51 \% & 68 \% & 56 \% \\ \text { Chile } & 15 \% & 14 \% & 27 \% & 25 \% & 39 \% & 34 \% & 43 \% & 37 \% & 47 \% & 38 \% & 52 \% & 41 \% \\ \text { Colombia } & 7 \% & 7 \% & 21 \% & 20 \% & 35 \% & 32 \% & 43 \% & 39 \% & 46 \% & 41 \% & 59 \% & 47 \% \\ \text { Costa Rica } & 4 \% & 4 \% & 23 \% & 23 \% & 44 \% & 43 \% & 47 \% & 44 \% & 50 \% & 47 \% & 60 \% & 50 \% \\ \text { Cuba } & 1 \% & 1 \% & 11 \% & 10 \% & 36 \% & 29 \% & 54 \% & 41 \% & 59 \% & 44 \% & 80 \% & 50 \% \\ \text { Ecuador } & 7 \% & 7 \% & 20 \% & 18 \% & 35 \% & 31 \% & 43 \% & 36 \% & 47 \% & 38 \% & 61 \% & 42 \% \\ \text { Guatemala } & 3 \% & 3 \% & 7 \% & 7 \% & 21 \% & 20 \% & 35 \% & 33 \% & 47 \% & 43 \% & 74 \% & 61 \% \\ \text { Guyana } & 46 \% & 46 \% & 58 \% & 56 \% & 59 \% & 58 \% & 62 \% & 60 \% & 67 \% & 65 \% & 100 \% & 95 \% \\ \text { Honduras } & 5 \% & 5 \% & 22 \% & 21 \% & 41 \% & 39 \% & 52 \% & 48 \% & 56 \% & 51 \% & 64 \% & 57 \% \\ \text { Mexico } & 8 \% & 8 \% & 19 \% & 18 \% & 34 \% & 31 \% & 43 \% & 38 \% & 49 \% & 42 \% & 62 \% & 49 \% \\ \text { Nicaragua } & 12 \% & 12 \% & 26 \% & 26 \% & 47 \% & 44 \% & 56 \% & 51 \% & 62 \% & 56 \% & 75 \% & 60 \% \\ \text { Paraguay } & 20 \% & 20 \% & 35 \% & 35 \% & 42 \% & 42 \% & 47 \% & 46 \% & 51 \% & 50 \% & 57 \% & 53 \% \\ \text { Peru } & 17 \% & 17 \% & 32 \% & 32 \% & 43 \% & 42 \% & 48 \% & 46 \% & 52 \% & 48 \% & 59 \% & 52 \% \\ \text { Panama } & 14 \% & 14 \% & 32 \% & 32 \% & 44 \% & 44 \% & 55 \% & 54 \% & 60 \% & 59 \% & 84 \% & 73 \% \\ \text { Uruguay } & 40 \% & 40 \% & 45 \% & 45 \% & 46 \% & 46 \% & 59 \% & 58 \% & 59 \% & 58 \% & 60 \% & 58 \% \\ \text { Venezuela } & 11 \% & 10 \% & 23 \% & 22 \% & 34 \% & 31 \% & 39 \% & 34 \% & 44 \% & 37 \% & 62 \% & 45 \% \\ \text { LCR Totals } & 13 \% & 13 \% & 26 \% & 25 \% & 39 \% & 36 \% & 46 \% & 42 \% & 50 \% & 45 \% & 64 \% & 52 \%\end{array}$

Source: Population and density are from CIESIN Gridded Population of the World 3. Notes:

1) LCR totals include all Latin American and Caribbean countries, including those that do not appear in the table.

2) There were a small number of coastal gridcells that were missing country codes, and were therefore omitted from the above table.

3) The denominator for the percentage was total population as given by the tabulated cells, and excluding those few cells with omitted country codes.

4) "Remote" means that the gridcell is located an hour or greater away from a city of 100,000 people. 
Table 3. Proportion of total population, by hours to city of 100,000 and low population density

\author{
Hours to city of 100,000 people \\ $<1$ \\ $1-4$ \\ $>4$ \\ All $<150$ I \\ All $<150 I$ \\ sq. $\mathrm{km}$. \\ All $<150 I$ \\ sq. $\mathbf{k m}$.
}

Argentina

$50 \% \quad 3 \%$

$29 \% \quad 23 \% \quad 21 \% \quad 21 \%$

Bolivia

$20 \% \quad 3 \%$

$37 \%$

$22 \%$

$43 \% \quad 31 \%$

Brazil

$42 \% \quad 4 \%$

$40 \%$

$31 \%$

$18 \% \quad 18 \%$

Chile

Colombia

$40 \% \quad 7 \%$

$51 \%$

$28 \%$

$9 \% \quad 8 \%$

Costa Rica

$42 \% \quad 4 \%$

$46 \%$

$28 \%$

$13 \% \quad 11 \%$

Cuba

$49 \% \quad 2 \%$

$30 \%$

$23 \%$

$21 \% \quad 21 \%$

Ecuador

Guatemala

$50 \% \quad 13 \%$

$49 \%$

$40 \%$

$1 \% \quad 1 \%$

$49 \% \quad 8 \%$

$43 \%$

$29 \%$

$9 \% \quad 7 \%$

Guyana

Honduras

$35 \% \quad 3 \%$

$26 \%$

$6 \% \quad 6 \%$

$5 \% \quad 2 \% \quad 26 \% \quad 8 \% \quad 69 \% \quad 52 \%$

Mexico

$33 \% \quad 4 \%$

$43 \%$

$5 \% \quad 5 \%$

Nicaragua

$47 \% \quad 5 \%$

$62 \%$

$28 \%$

$10 \% \quad 10 \%$

$35 \% \quad 5 \%$

$34 \%$

$17 \% \quad 17 \%$

$45 \% \quad 1 \%$

$14 \%$

$35 \% \quad 32 \%$

Peru

$43 \% \quad 2 \%$

$16 \%$

$36 \% \quad 30 \%$

$26 \% \quad 1 \%$

$13 \%$

$48 \% \quad 42 \%$

$37 \% \quad 1 \%$

$18 \%$

$40 \% \quad 40 \%$

Venezuela

$51 \% \quad 5 \%$

$26 \%$

$10 \% \quad 8 \%$

LCR Totals

$43 \% \quad 4 \%$

$27 \%$

$15 \%$

Source: Population and density are from CIESIN Gridded Population of the World 3.

Notes:

1) LCR totals include all Latin American and Caribbean countries, including those that do not appear in the table.

2) There were a small number of coastal gridcells that were missing country codes, and were therefore omitted from the above table.

3) The denominator for the percentage was total population as given by the tabulated cells, and excluding those few cells with omitted country codes. 
Table 4. Proportion of total population, by land category and low population density

Land category

Suitable for rainfed crops, not forested

$$
\begin{aligned}
& \text { All }<150 I \\
& \text { sq. } \mathrm{km} \text {. }
\end{aligned}
$$

\section{Unsuitable for Good for rainfed rainfed crops, crops, forested} not forested

$$
\begin{gathered}
\text { All }<150 l \\
\text { sq. } \mathrm{km} .
\end{gathered}
$$

\section{Unsuitable for rainfed crops, forested}

$$
\begin{aligned}
& \text { All }<150 I \\
& \text { sq. } \mathrm{km} \text {. }
\end{aligned}
$$

$\begin{array}{lrrrrrrrr}\text { Argentina } & 76 \% & 28 \% & 21 \% & 16 \% & 2 \% & 2 \% & 1 \% & 1 \% \\ \text { Bolivia } & 28 \% & 10 \% & 50 \% & 31 \% & 16 \% & 11 \% & 5 \% & 3 \% \\ \text { Brazil } & 66 \% & 33 \% & 19 \% & 10 \% & 10 \% & 8 \% & 5 \% & 3 \% \\ \text { Chile } & 21 \% & 7 \% & 60 \% & 24 \% & 7 \% & 4 \% & 12 \% & 9 \% \\ \text { Colombia } & 20 \% & 10 \% & 55 \% & 18 \% & 7 \% & 6 \% & 18 \% & 9 \% \\ \text { Costa Rica } & 5 \% & 5 \% & 12 \% & 8 \% & 7 \% & 7 \% & 76 \% & 26 \% \\ \text { Cuba } & 82 \% & 41 \% & 3 \% & 2 \% & 8 \% & 7 \% & 8 \% & 5 \% \\ \text { Ecuador } & 60 \% & 22 \% & 35 \% & 18 \% & 2 \% & 2 \% & 3 \% & 2 \% \\ \text { Guatemala } & 7 \% & 5 \% & 50 \% & 10 \% & 7 \% & 5 \% & 36 \% & 15 \% \\ \text { Guyana } & 25 \% & 12 \% & 9 \% & 3 \% & 52 \% & 41 \% & 14 \% & 8 \% \\ \text { Honduras } & 19 \% & 8 \% & 28 \% & 16 \% & 11 \% & 6 \% & 42 \% & 23 \% \\ \text { Mexico } & 42 \% & 13 \% & 35 \% & 19 \% & 10 \% & 4 \% & 12 \% & 7 \% \\ \text { Nicaragua } & 42 \% & 19 \% & 29 \% & 19 \% & 9 \% & 6 \% & 20 \% & 12 \% \\ \text { Paraguay } & 68 \% & 22 \% & 3 \% & 2 \% & 25 \% & 19 \% & 4 \% & 3 \% \\ \text { Peru } & 8 \% & 6 \% & 80 \% & 33 \% & 7 \% & 5 \% & 5 \% & 4 \% \\ \text { Panama } & 31 \% & 16 \% & 19 \% & 10 \% & 13 \% & 6 \% & 38 \% & 23 \% \\ \text { Uruguay } & 98 \% & 58 \% & 2 \% & 2 \% & 0 \% & 0 \% & 0 \% & 0 \% \\ \text { Venezuela } & 48 \% & 19 \% & 17 \% & 6 \% & 22 \% & 10 \% & 13 \% & 4 \% \\ \text { LCR Totals } & 48 \% & 20 \% & 32 \% & 14 \% & 10 \% & 6 \% & 11 \% & 5 \%\end{array}$

Sources:

1) Population and density are from CIESIN Gridded Population of the World 3.

2) Rainfed crop suitability data are from FAO/IIASA Global Agro-Ecological Zones. Notes:

1) LCR totals include all Latin American and Caribbean countries, including those that do not appear in the table.

2) There were a small number of coastal gridcells that were missing country codes, and were therefore omitted from the above table.

3) The denominator for the percentage was total population as given by the tabulated cells, and excluding those few cells with omitted country codes.

4) "Unsuitable" include GAEZ classifications marginal, very marginal and not suitable. 
Table 5. Proportion of total land area, by land category and low population density

Land category

Suitable for rainfed crops, not forested

$$
\begin{aligned}
& \text { All }<150 / \\
& \text { sq. } \mathrm{km} .
\end{aligned}
$$

$$
\begin{aligned}
& \text { Unsuitable for } \\
& \text { rainfed crops, } \\
& \text { not forested }
\end{aligned}
$$

$$
\begin{aligned}
& \text { All }<150 \text { I } \\
& \text { sq. km. }
\end{aligned}
$$

\section{Suitable for rainfed crops, forested}

$$
\text { All } \begin{array}{r}
<150 ~ I \\
\text { sq. } \mathrm{km} .
\end{array}
$$

$\begin{array}{lrrrrrrrr}\text { Argentina } & 37 \% & 36 \% & 60 \% & 60 \% & 1 \% & 1 \% & 2 \% & 2 \% \\ \text { Bolivia } & 31 \% & 30 \% & 28 \% & 28 \% & 37 \% & 37 \% & 4 \% & 4 \% \\ \text { Brazil } & 35 \% & 34 \% & 15 \% & 15 \% & 35 \% & 35 \% & 15 \% & 15 \% \\ \text { Chile } & 5 \% & 5 \% & 68 \% & 67 \% & 4 \% & 4 \% & 23 \% & 23 \% \\ \text { Colombia } & 21 \% & 20 \% & 20 \% & 19 \% & 28 \% & 28 \% & 31 \% & 30 \% \\ \text { Costa Rica } & 10 \% & 10 \% & 18 \% & 18 \% & 17 \% & 17 \% & 54 \% & 48 \% \\ \text { Cuba } & 75 \% & 66 \% & 3 \% & 2 \% & 14 \% & 13 \% & 9 \% & 8 \% \\ \text { Ecuador } & 28 \% & 25 \% & 37 \% & 35 \% & 14 \% & 14 \% & 21 \% & 21 \% \\ \text { Guatemala } & 10 \% & 9 \% & 24 \% & 15 \% & 31 \% & 31 \% & 34 \% & 26 \% \\ \text { Guyana } & 10 \% & 10 \% & 2 \% & 2 \% & 63 \% & 63 \% & 25 \% & 25 \% \\ \text { Honduras } & 12 \% & 12 \% & 25 \% & 24 \% & 17 \% & 16 \% & 45 \% & 44 \% \\ \text { Mexico } & 18 \% & 16 \% & 58 \% & 56 \% & 9 \% & 9 \% & 15 \% & 15 \% \\ \text { Nicaragua } & 23 \% & 21 \% & 16 \% & 15 \% & 32 \% & 32 \% & 28 \% & 28 \% \\ \text { Paraguay } & 54 \% & 53 \% & 25 \% & 25 \% & 18 \% & 17 \% & 4 \% & 4 \% \\ \text { Peru } & 5 \% & 5 \% & 41 \% & 40 \% & 23 \% & 23 \% & 31 \% & 31 \% \\ \text { Panama } & 21 \% & 19 \% & 18 \% & 17 \% & 18 \% & 17 \% & 44 \% & 42 \% \\ \text { Uruguay } & 97 \% & 97 \% & 3 \% & 3 \% & 0 \% & 0 \% & 0 \% & 0 \% \\ \text { Venezuela } & 37 \% & 35 \% & 7 \% & 6 \% & 28 \% & 28 \% & 28 \% & 28 \% \\ \text { LCR Totals } & 30 \% & 29 \% & 29 \% & 29 \% & 25 \% & 25 \% & 16 \% & 16 \%\end{array}$

\section{Sources:}

1) Population density is from CIESIN Gridded Population of the World 3.

2) Rainfed crop suitability data are from FAO/IIASA Global Agro-Ecological Zones. Notes:

1) LCR totals include all Latin American and Caribbean countries, including those that do not appear in the table.

2) There were a small number of coastal gridcells that were missing country codes, and were therefore omitted from the above table.

3) The denominator for the percentage was total area as given by the tabulated cells, and excluding those few cells with omitted country codes.

4) "Unsuitable" includes GAEZ classifications of 'marginal', 'very marginal', and 'not suitable'. 
Table 6. Population, area and grid cells from GPW 3.

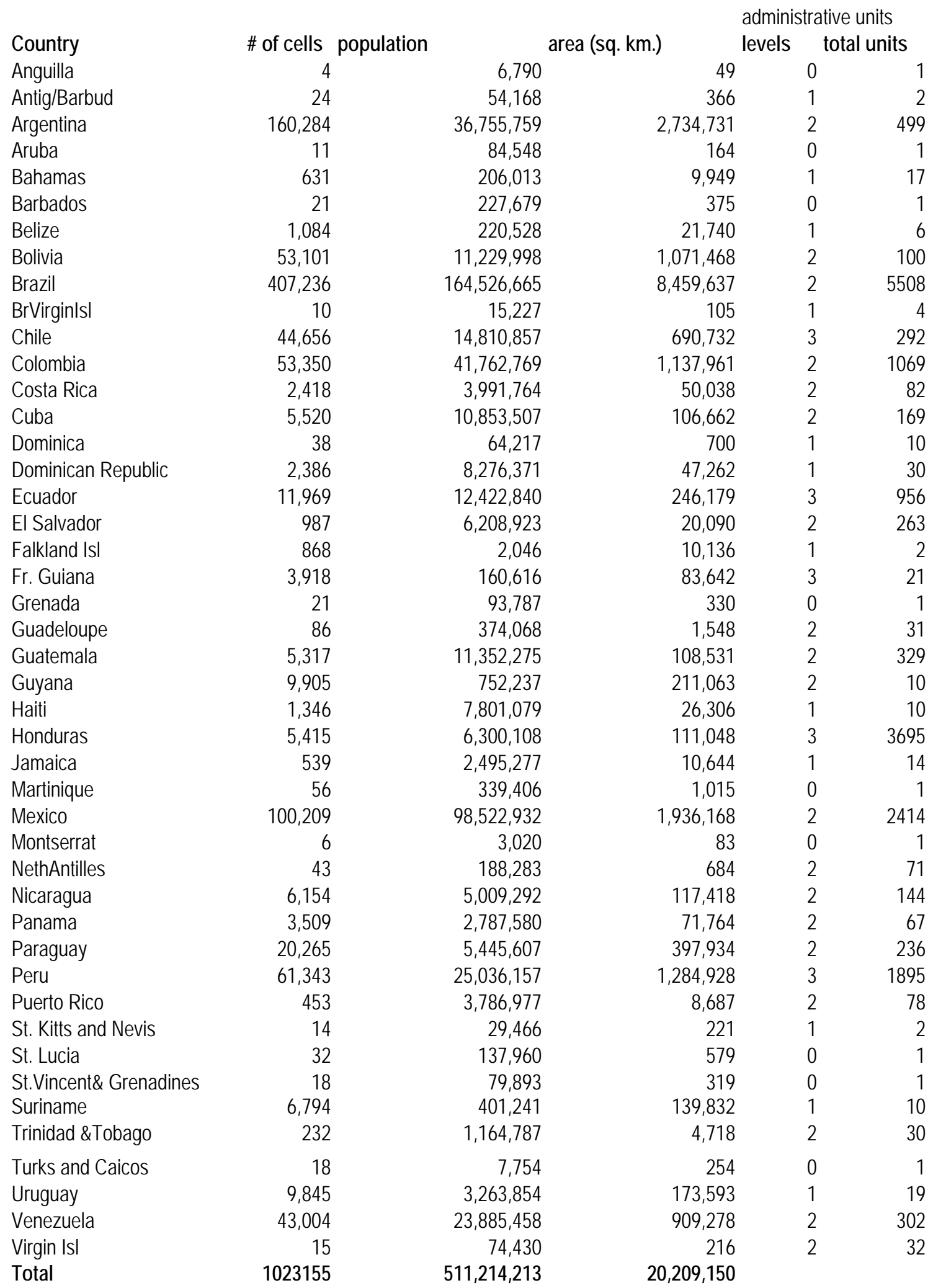


Table 7. Proportion of total population, by land category and low population density

Land category

Suitable for rainfed crops, not forested

All $<150$ I sq. $\mathrm{km}$.

Argentina

Bolivia

Brazil

Chile

Colombia

Costa Rica

Cuba

Ecuador

Guatemala

Guyana

Honduras

Mexico

Nicaragua

Paraguay

Peru

Panama

Uruguay

Venezuela

LCR Totals

\section{Unsuitable for Good for rainfed rainfed crops, crops, forested not forested}

$$
\text { All }<150 \text { I }
$$

sq. $\mathrm{km}$.

All $\begin{array}{r}<150 ~ I \\ \text { sq. } \mathrm{km} .\end{array}$

\section{Unsuitable for rainfed crops, forested}

All $<150 I$ sq. $\mathrm{km}$.

Sources:

1) Population and density are from CIESIN Gridded Population of the World 3.

2) Rainfed crop suitability data are from FAO/IIASA Global Agro-Ecological Zones. Notes:

1) LCR totals include all Latin American and Caribbean countries, including those that do not appear in the table.

2) There were a small number of coastal gridcells that were missing country codes, and were therefore omitted from the above table.

3) The denominator for the percentage was total population as given by the tabulated cells, and excluding those few cells with omitted country codes.

4) "Unsuitable" include GAEZ classifications marginal, very marginal and not suitable. 
Table 8. Proportion of total land area, by land category and low population density

Land category

Suitable for rainfed crops, not forested

\section{All $<150$ sq. $\mathrm{km}$.}

Argentina

Bolivia

Brazil

Chile

Colombia

Costa Rica

Cuba

Ecuador

Guatemala

Guyana

Honduras

Mexico

Nicaragua

Paraguay

Peru

Panama

Uruguay

Venezuela

LCR Totals

\section{Unsuitable for rainfed crops, not forested}

$$
\begin{array}{r}
\text { All } \begin{array}{c}
<150 l \\
\text { sq. } \mathrm{km} .
\end{array}
\end{array}
$$

\author{
Suitable for \\ rainfed crops, \\ forested
}

$$
\begin{array}{r}
\text { All }<150 \text { I } \\
\text { sq. } \mathrm{km} .
\end{array}
$$

\section{Unsuitable for rainfed crops, forested}

All < 150 I sq. km.

Sources:

1) Population density is from CIESIN Gridded Population of the World 3.

2) Rainfed crop suitability data are from FAO/IIASA Global Agro-Ecological Zones. Notes:

1) LCR totals include all Latin American and Caribbean countries, including those that do not appear in the table.

2) There were a small number of coastal gridcells that were missing country codes, and were therefore omitted from the above table.

3) The denominator for the percentage was total area as given by the tabulated cells, and excluding those few cells with omitted country codes.

4) "Unsuitable" includes GAEZ classifications of 'marginal', 'very marginal', and 'not suitable'. 
Figure 1: Gradient of remoteness, population density and poverty in Nicaragua

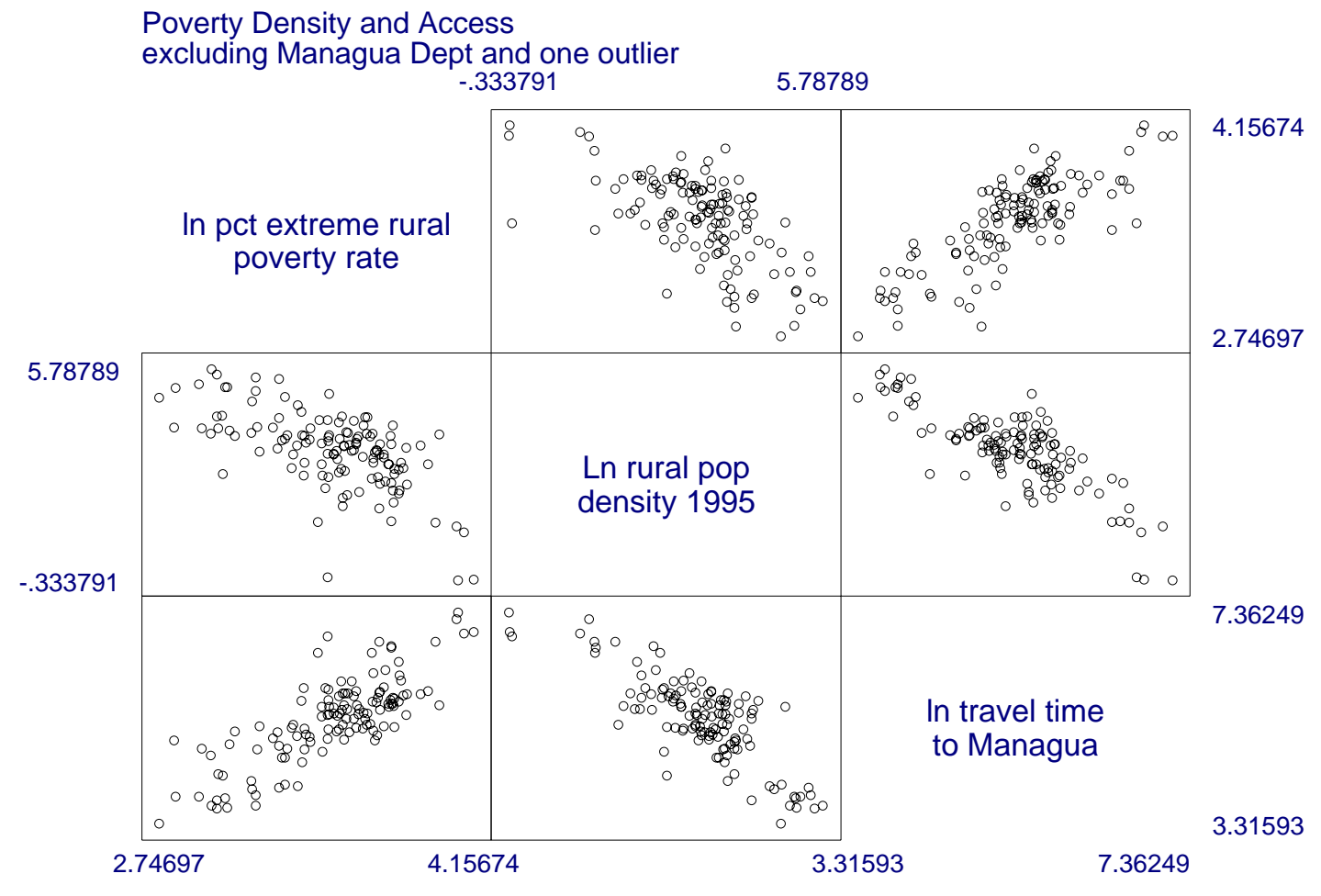


Figure 2. Imputed travel time to nearest city of 100,000 people

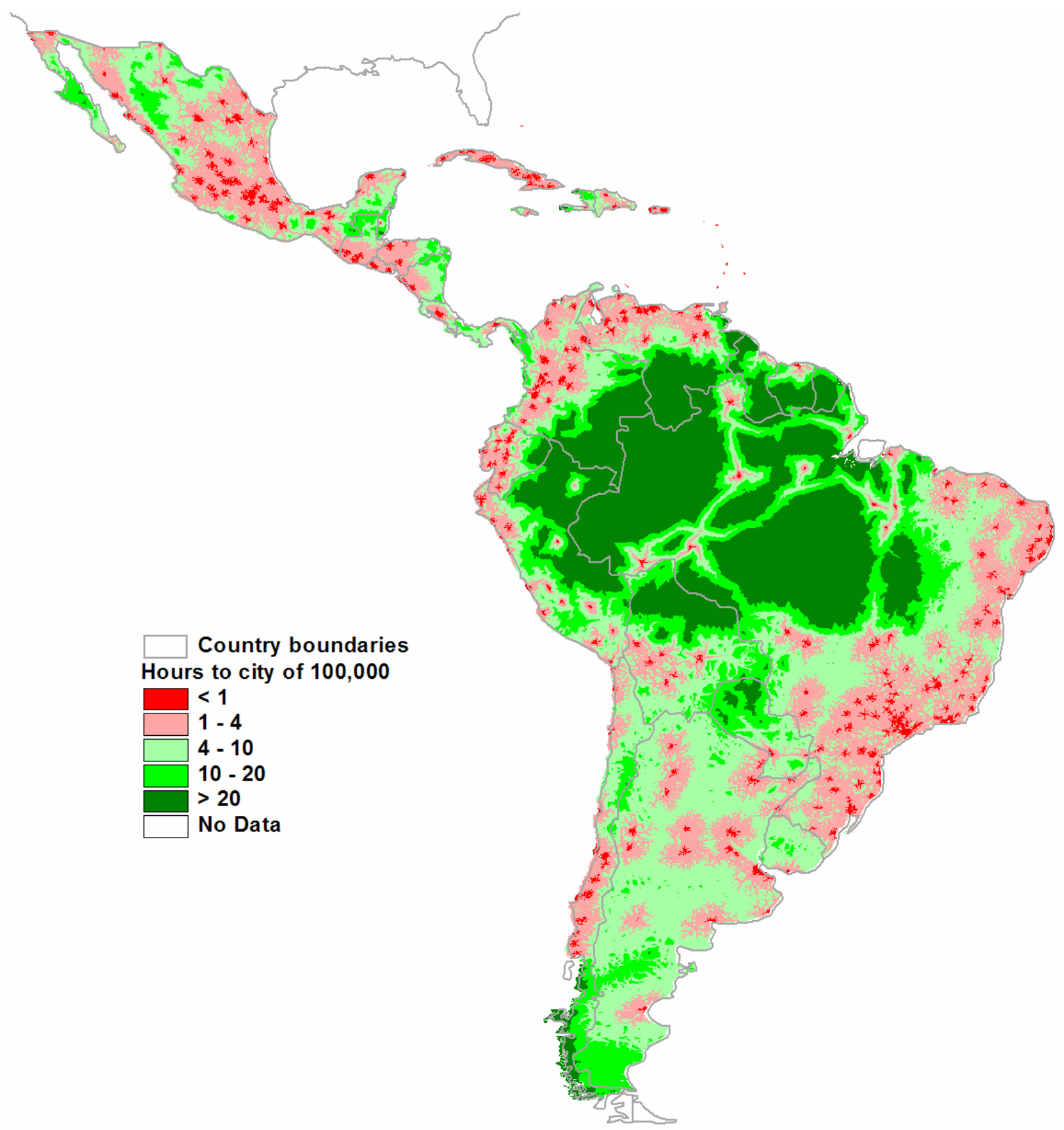

The denominations used and the boundaries shown on maps herein do not imply, on the part of the World Bank, any judgment on the legal basis of any territory or any endorsement or acceptance of such boundaries. 
Figure 3 Suitability for rainfed crops, and forest cover (Source: IIASA/FAO GAEZ)

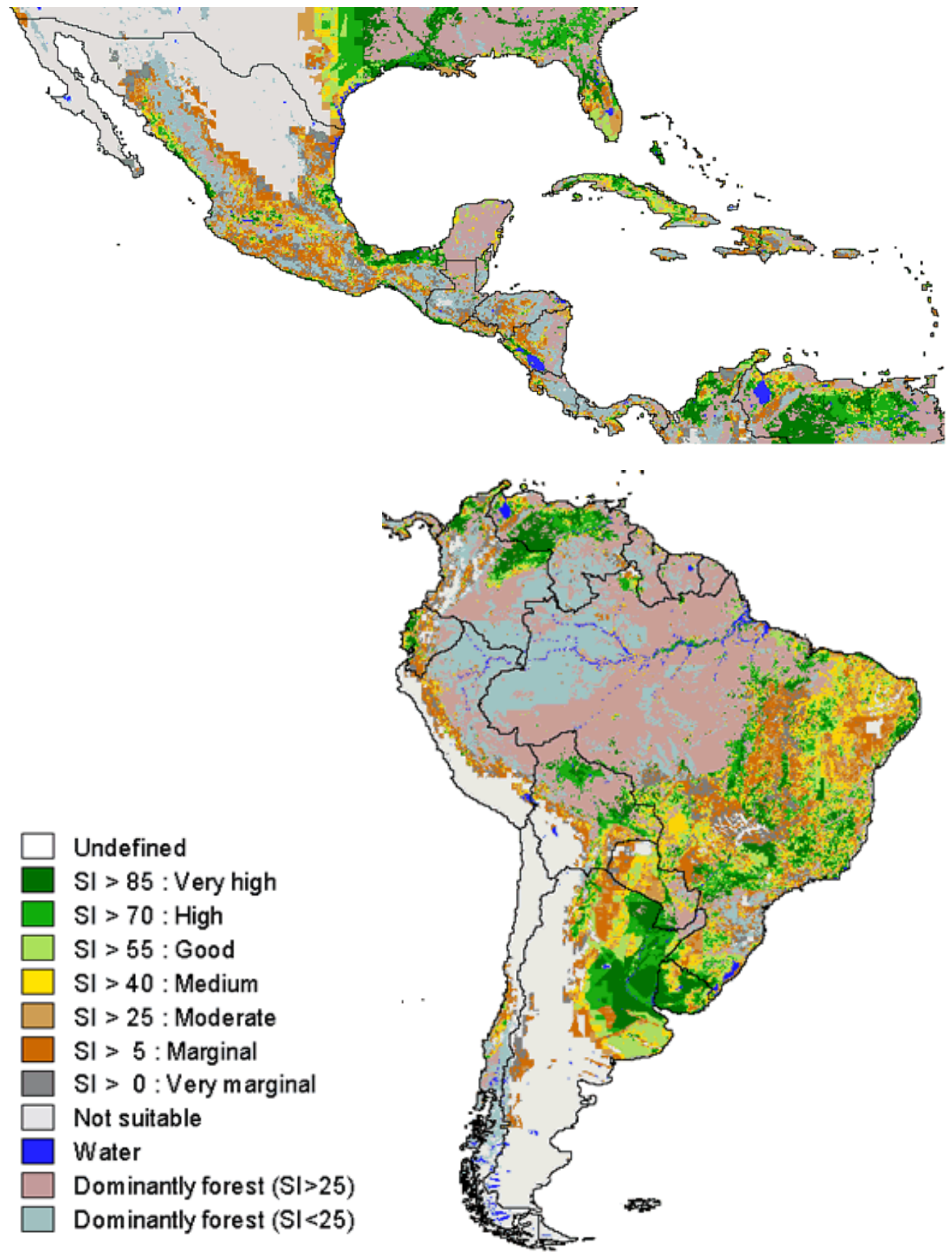

The denominations used and the boundaries shown on maps herein do not imply, on the part of the World Bank, any judgment on the legal basis of any territory or any endorsement or acceptance of such boundaries. 


\section{Figure 4 Population density from GPW 3}

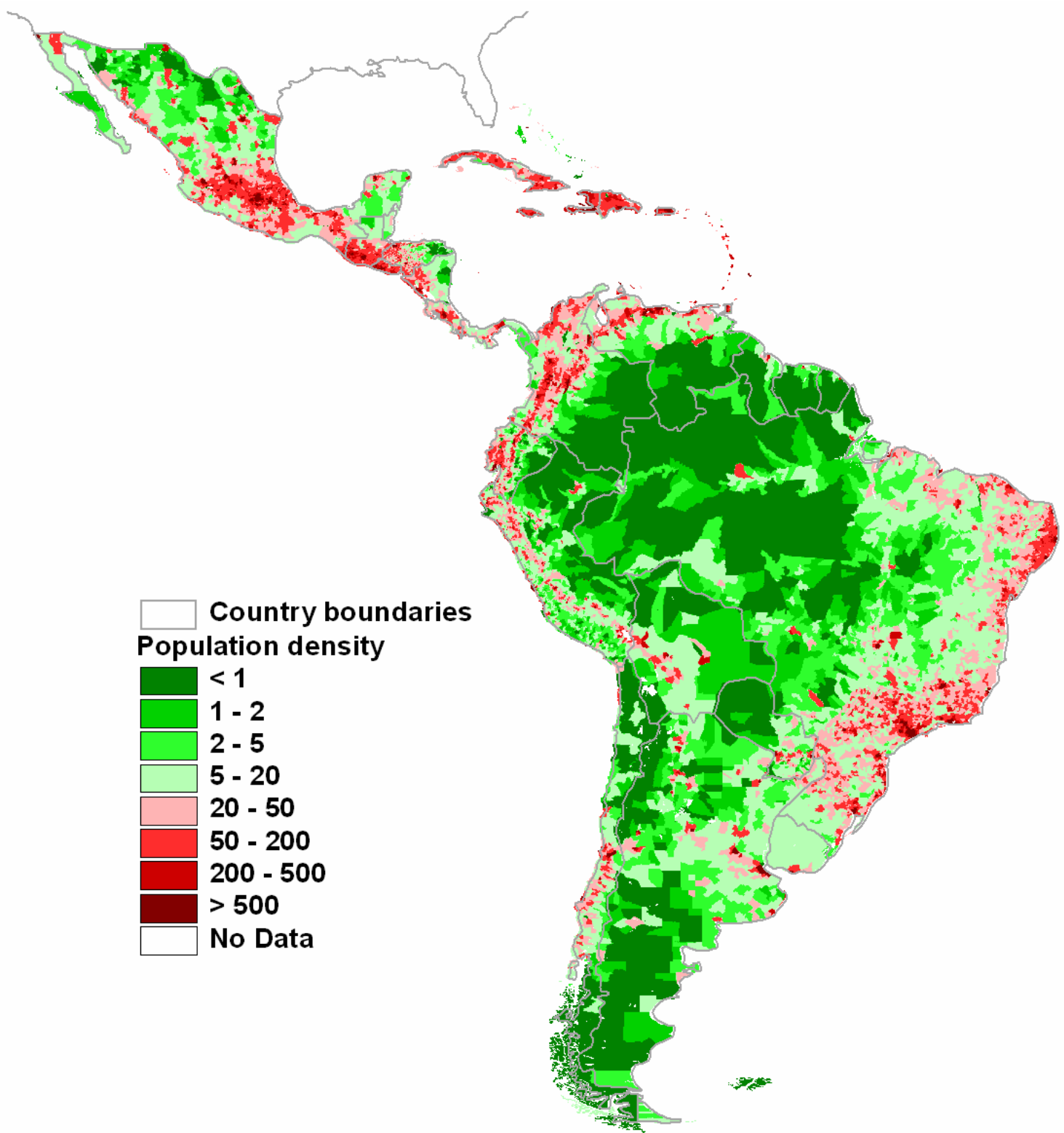

The denominations used and the boundaries shown on maps herein do not imply, on the part of the World Bank, any judgment on the legal basis of any territory or any endorsement or acceptance of such boundaries. 
Figure 5 Proportion of population more than 1 hour travel time from cities of 100,000 and below specified population density thresholds (GPW 3)

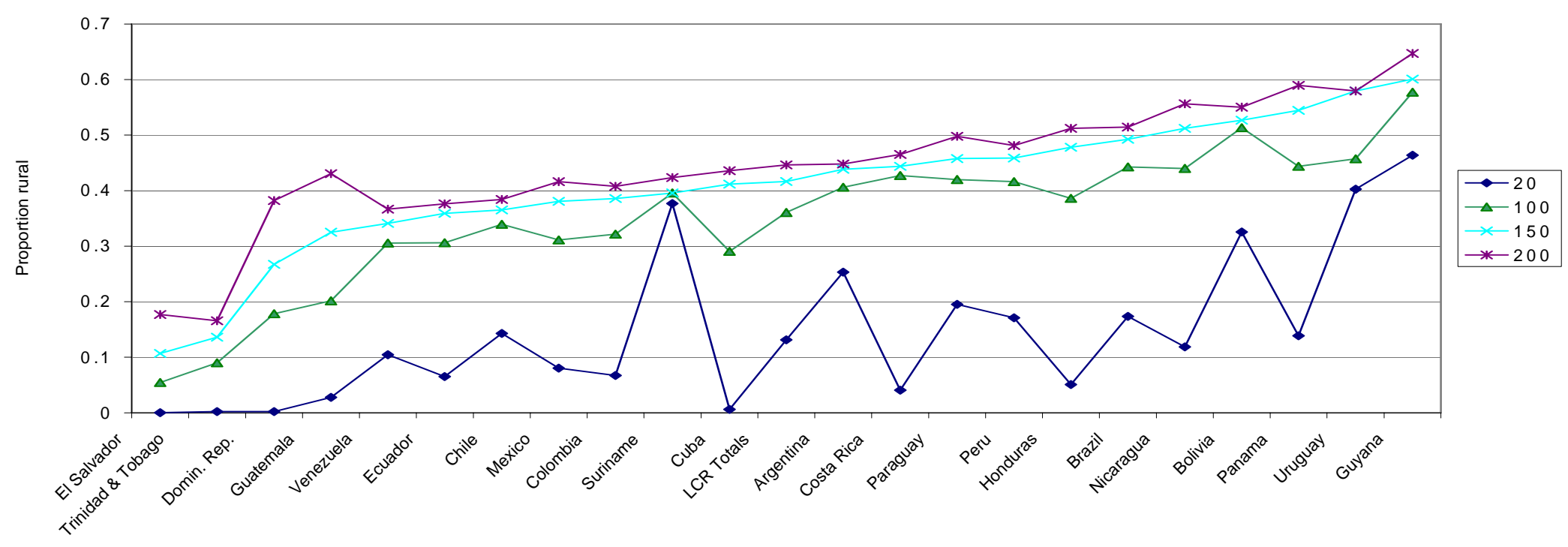




\section{APPENDIX FIGURES}
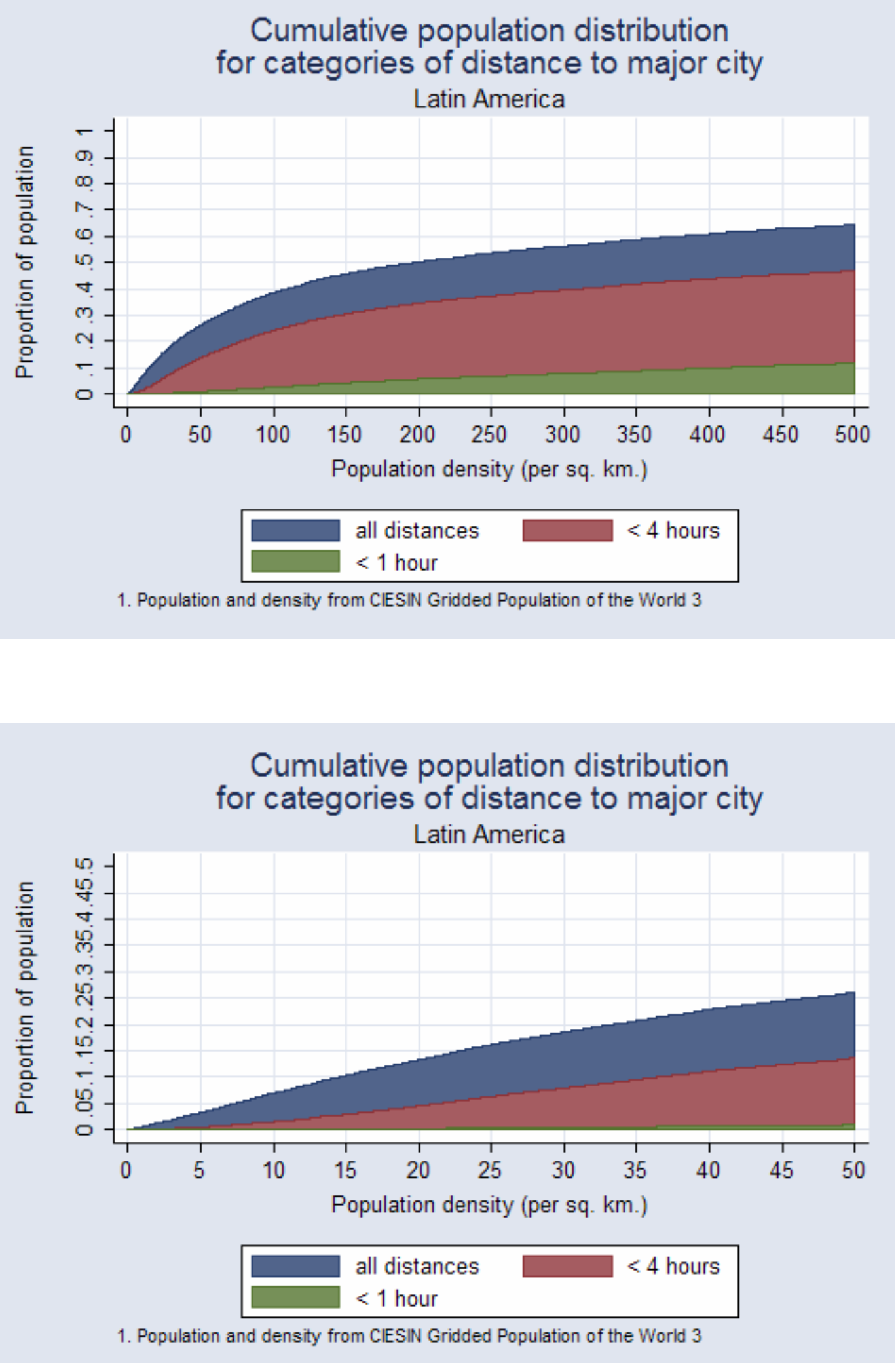

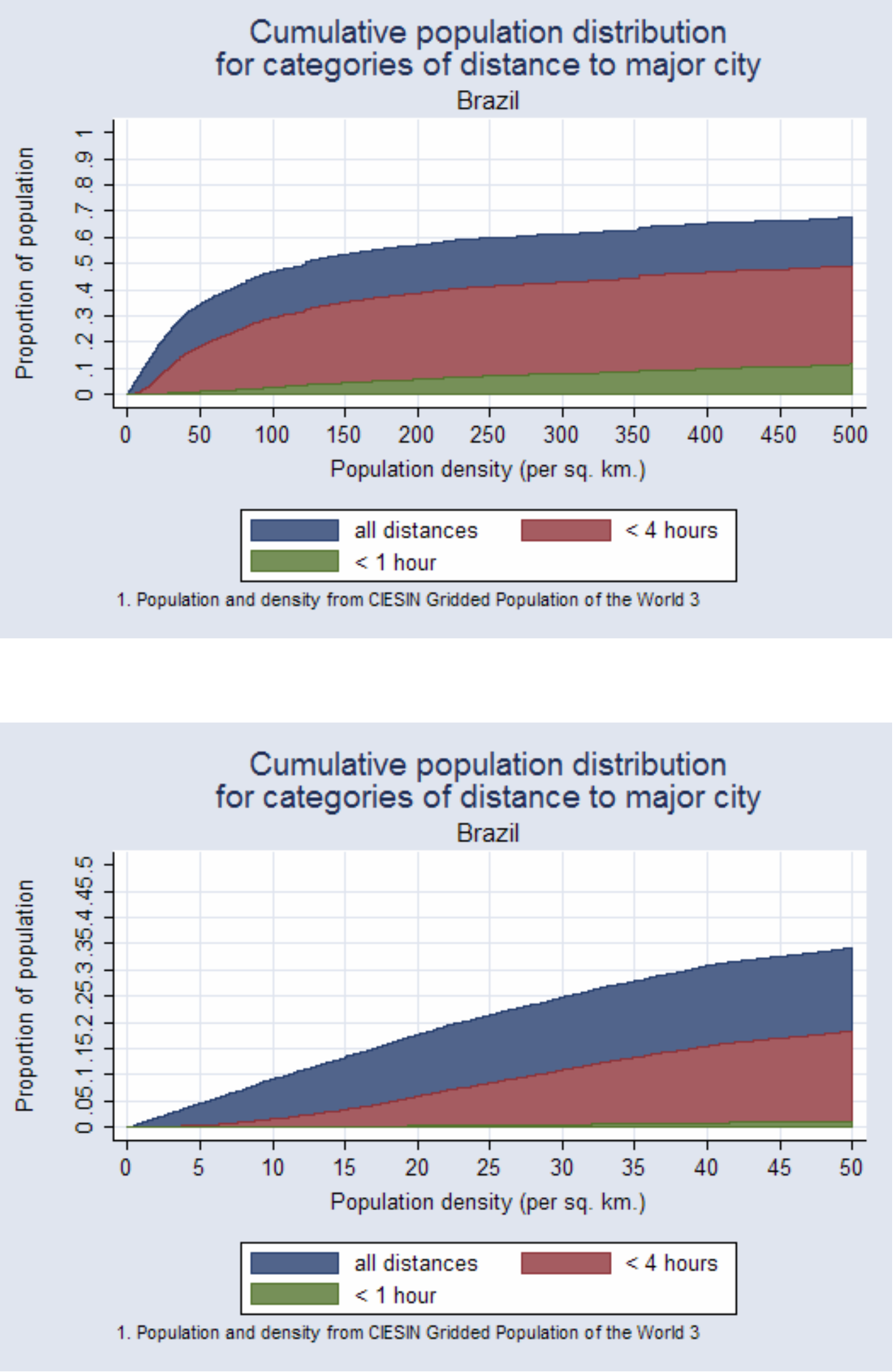

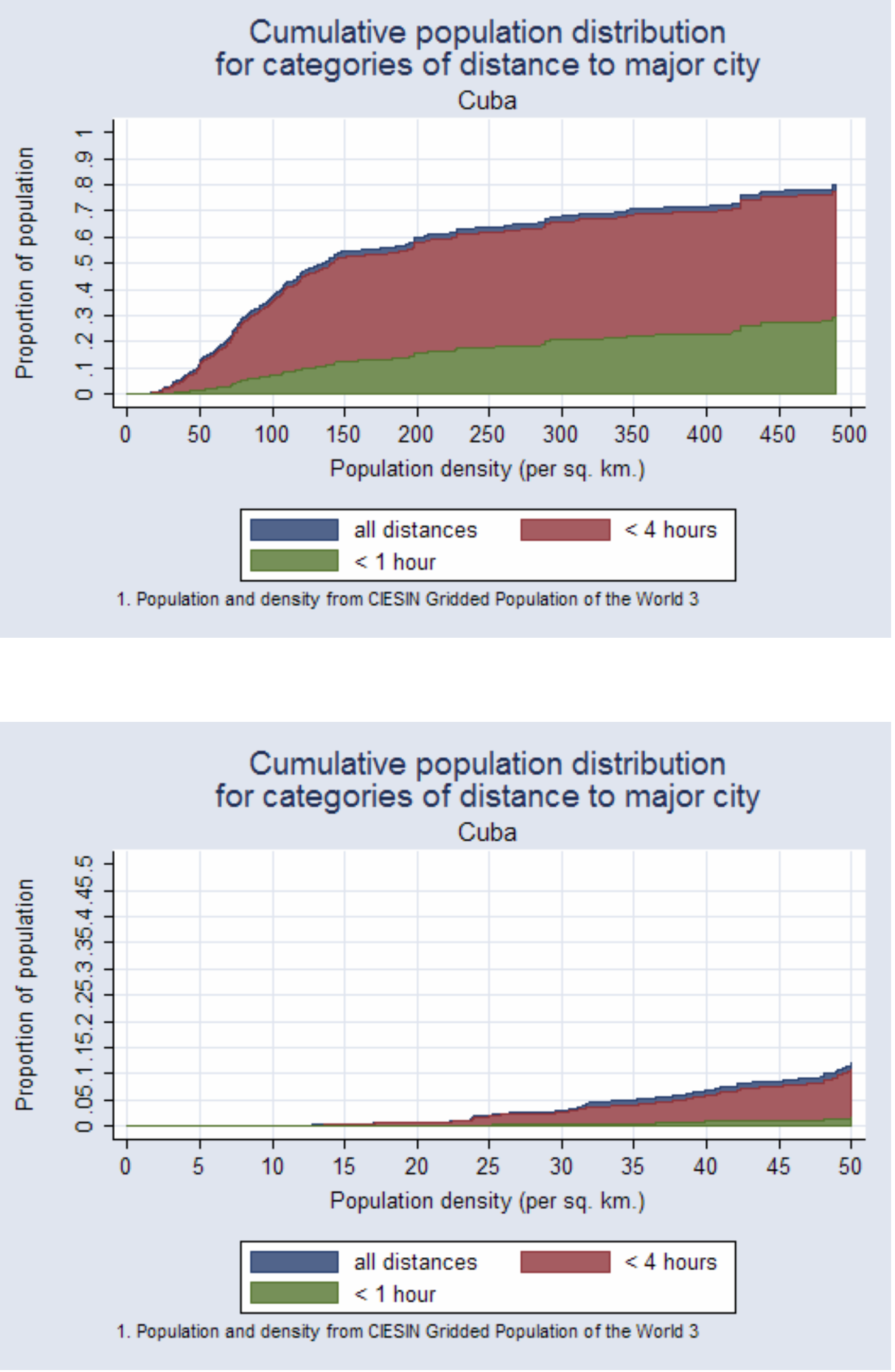

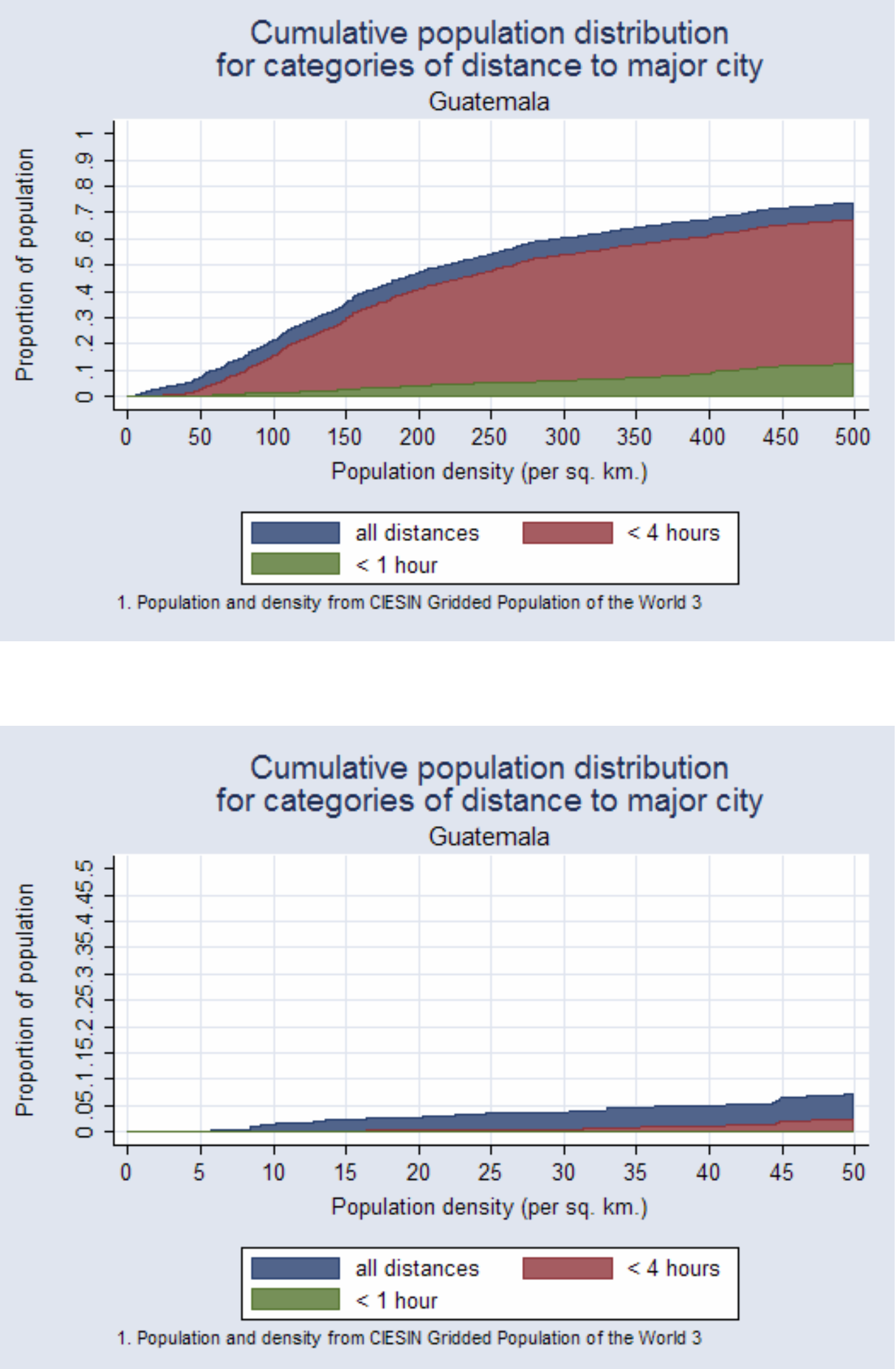

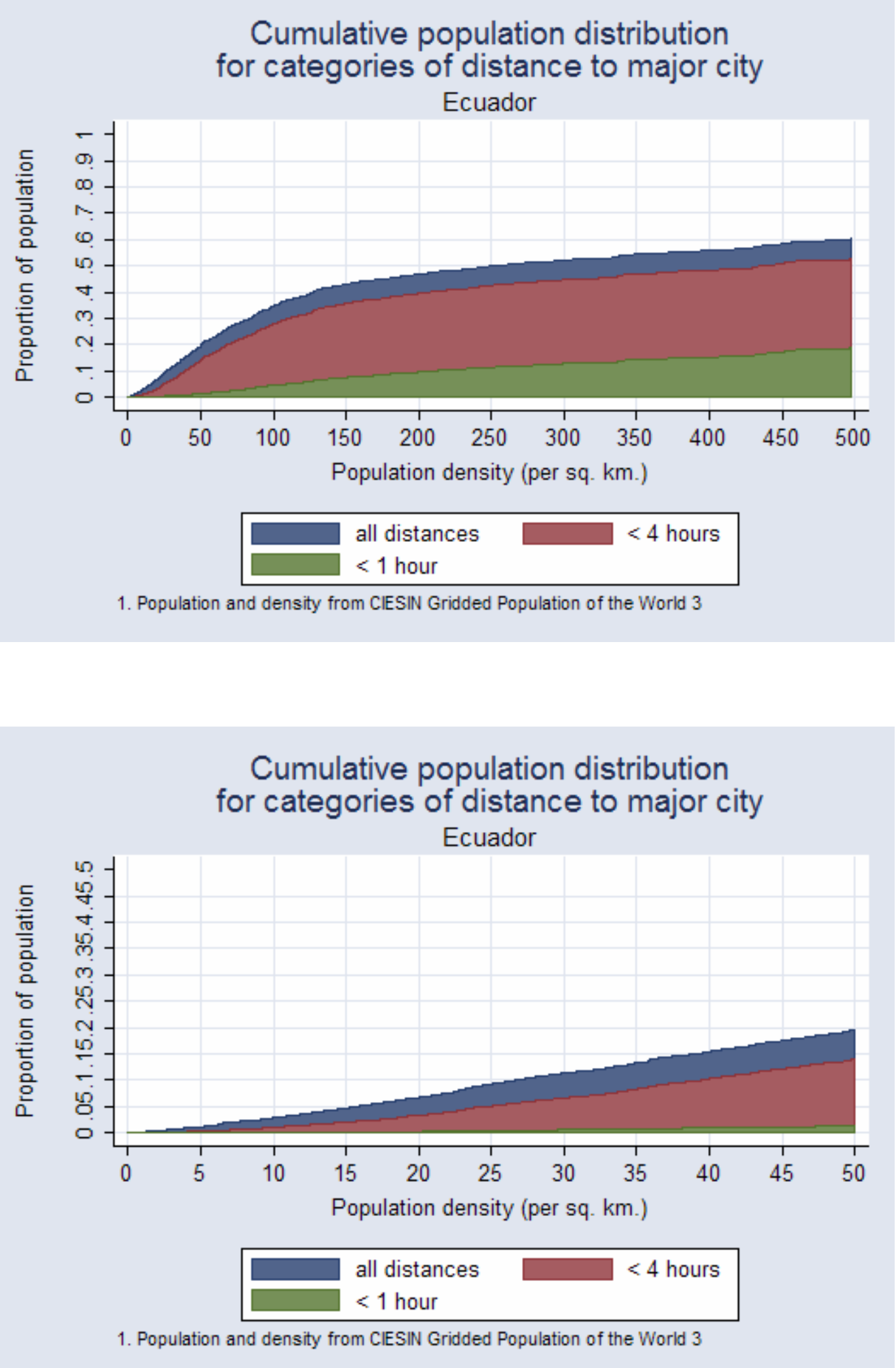

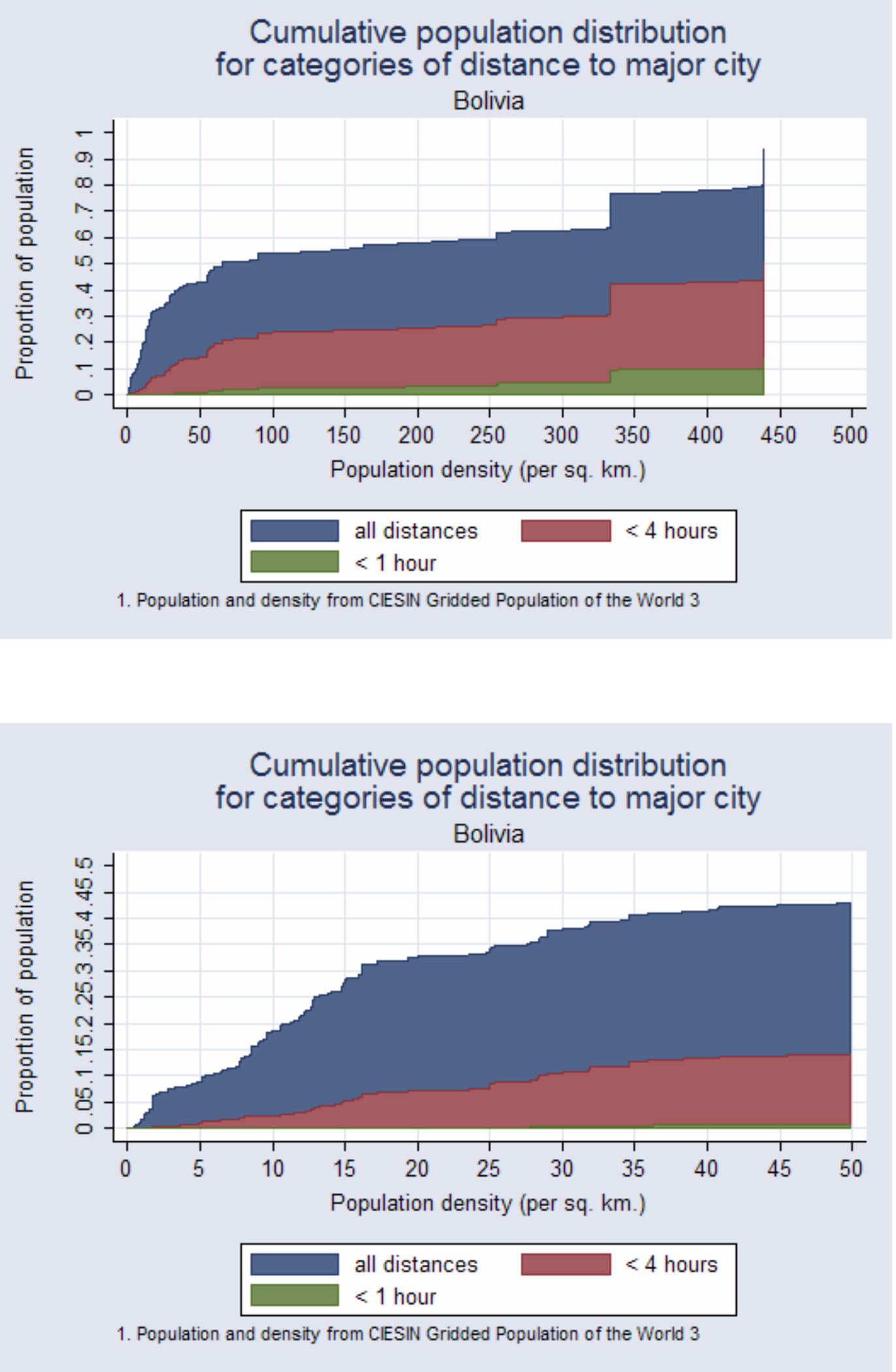

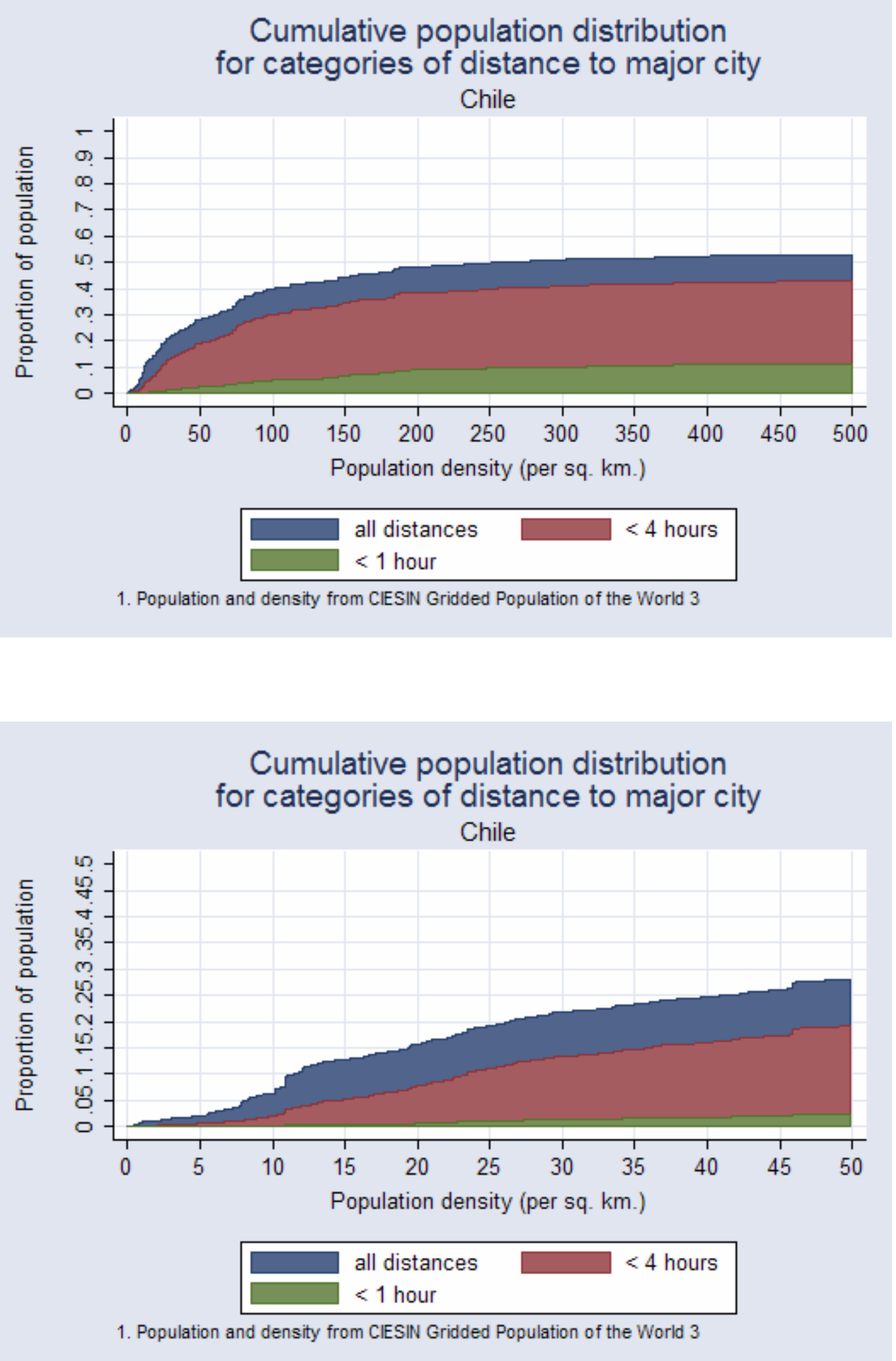

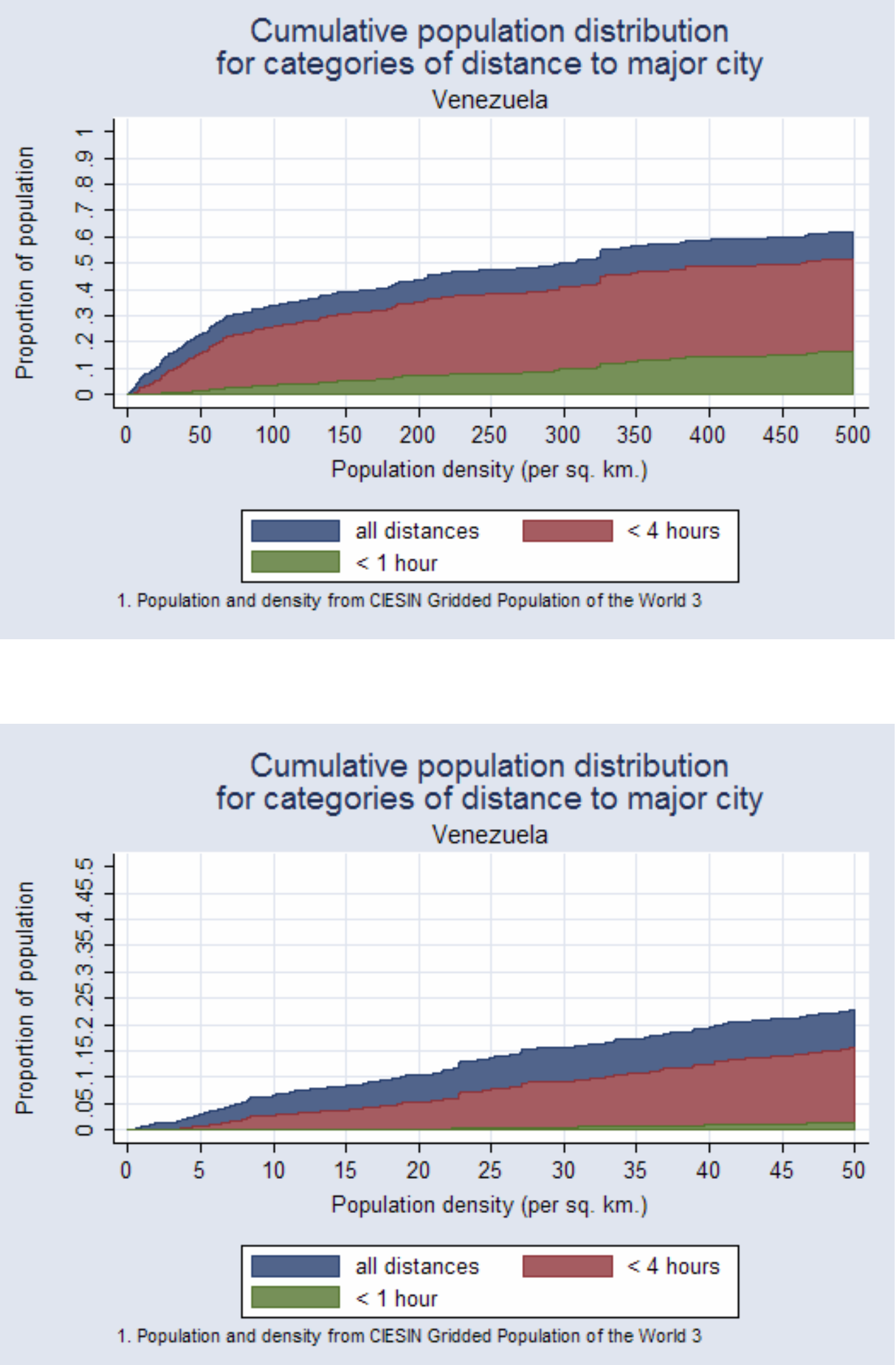

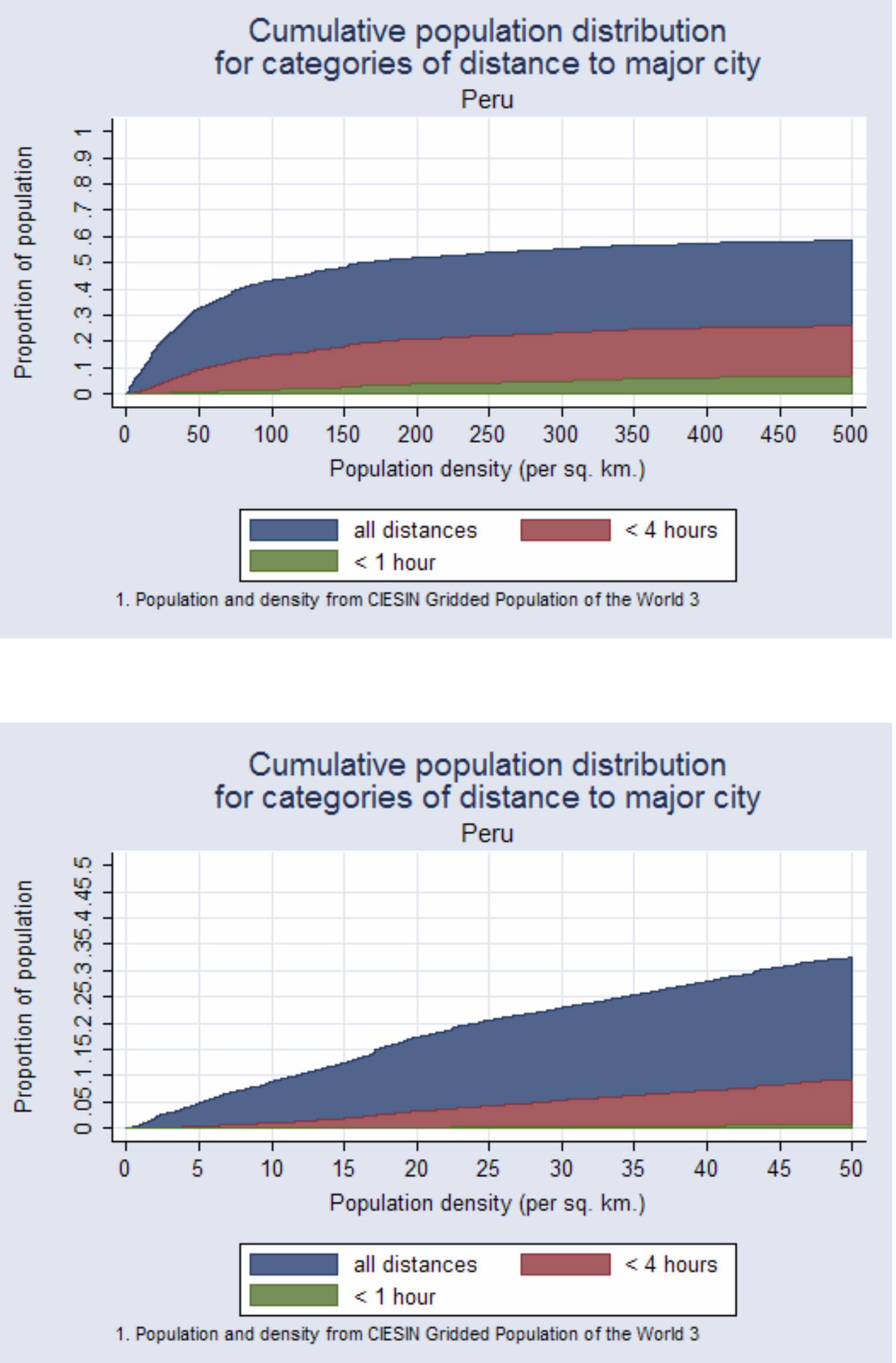

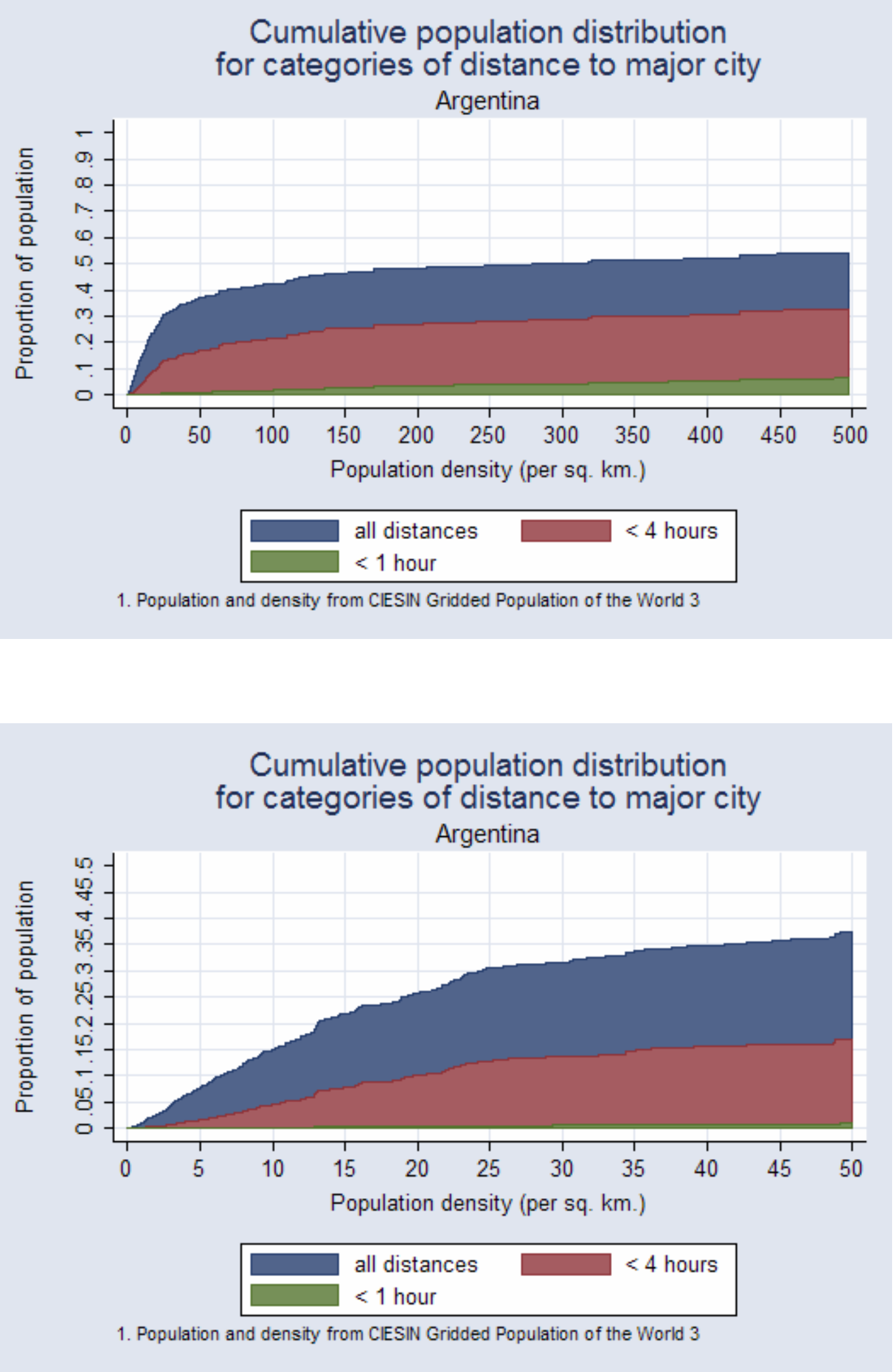

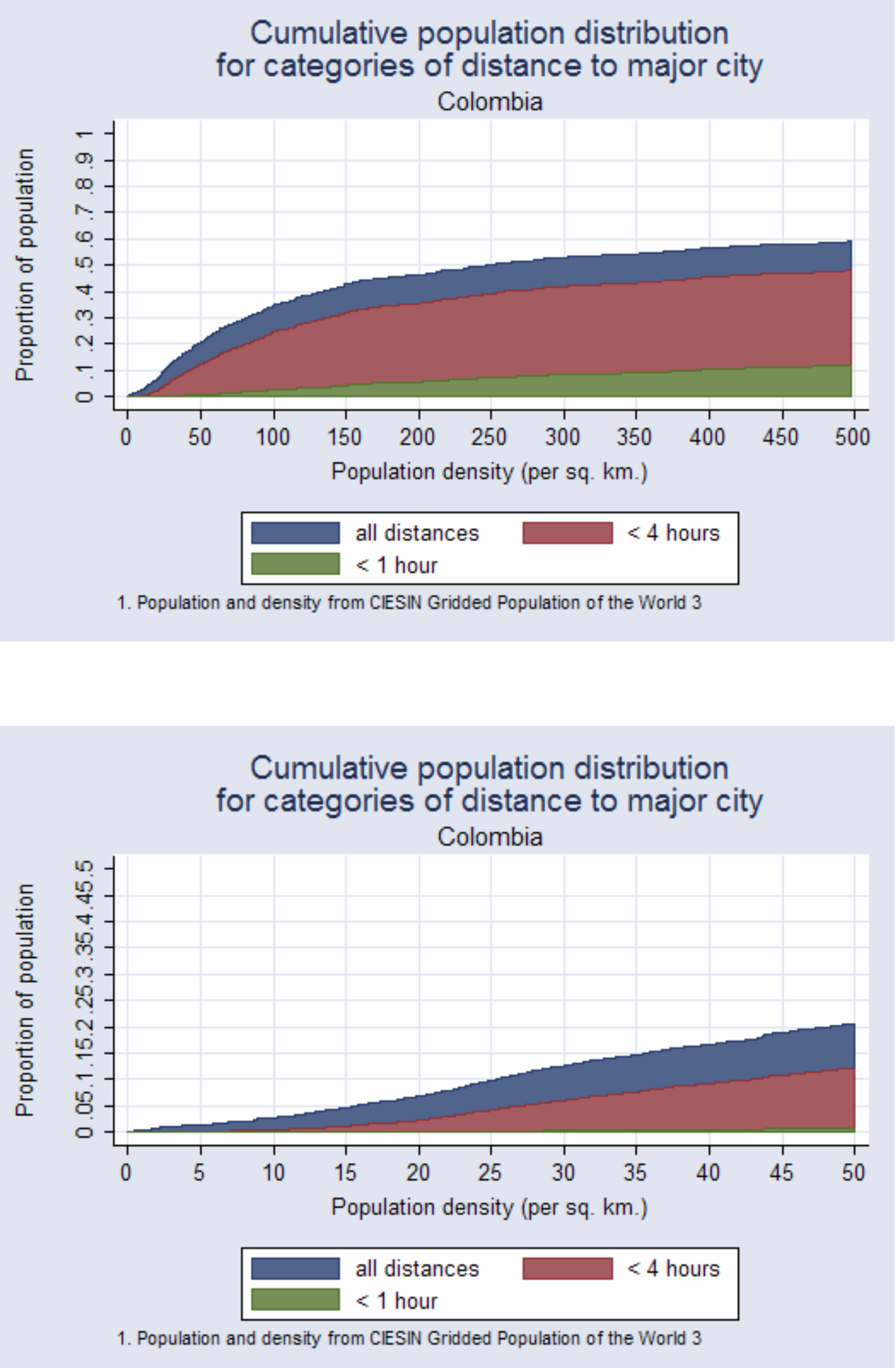

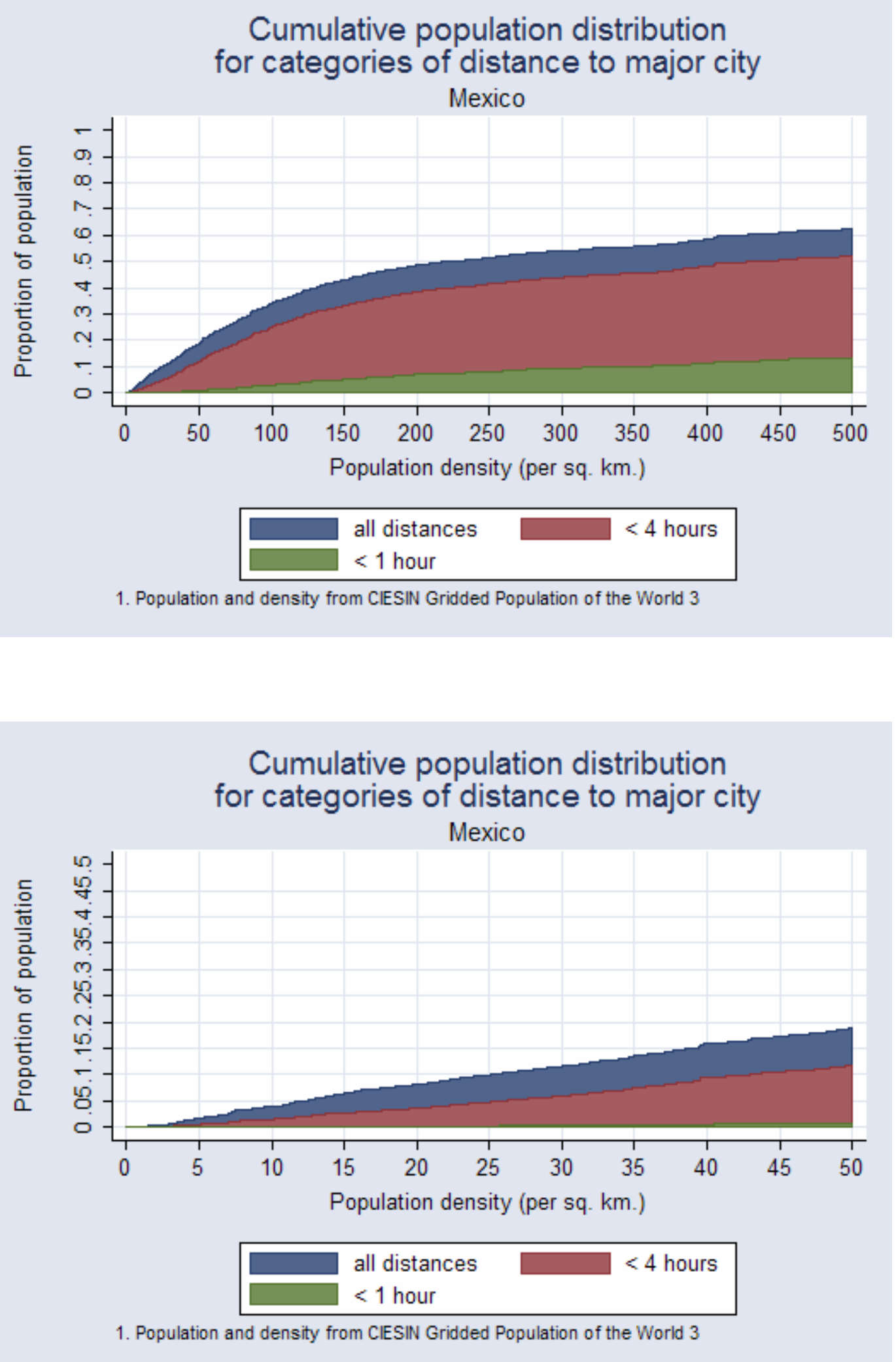